\title{
Using Volunteer-Employed Photography to Inform Tourism Planning Decisions: A Case Study of St David's Peninsula, Wales
}

\begin{abstract}
Tourism planning is widely considered to be a highly political process, particularly when tourism is only one of a number of possible land uses and there are numerous stakeholders, with a diversity of interests, all trying to influence the outcome. The winners are typically those holding power, while the losers are often the destination community, who lack sufficient power to influence planning decisions. New tools are therefore needed to empower wider stakeholder participation in the tourism planning process, and volunteer-employed photography (VEP) appears a promising option. This paper discusses the use of VEP to inform tourism planning on St David's Peninsula in Wales. As part of a National Park, the area attracts a large tourist numbers and is subject to relatively strict planning regulations, resulting in many land-use conflicts. Volunteers from two stakeholder groups - local residents and tourists - were given cameras and photo diaries, and asked to use it to comment on what they do and do not appreciate about the area, existing planning problems and ways to avoid future planning problems. Through this case study, the paper will examine the appropriateness of VEP as a tool for assisting tourism planning. The major finding is that a richer, deeper and more valuable dataset can be generated through the participation of host communities and visitors using the VEP approach. As a means of visually representing participants' views, VEP can be a powerful data collection and analysis tool, making a significant addition to the tourism planning toolkit at the local level.
\end{abstract}

Keywords: Photography, participatory planning, tourists, local community, visual methods 


\section{Introduction}

Researchers have argued persuasively that public participation is an essential component of tourism planning if it is to be effective (Gunn and Varr, 2002; Jamal and Kim, 2005; Milne and Ateljevic, 2001; Wearing et al., 2009b). Indeed, Spencer (2010) suggests that the most convincing argument for incorporating effective public participation techniques into the tourism planning process is that failing to do so can compromise the success of what is being planned. Writers such as Reed (1997) have also pointed out that tourism planning tends to be a political process, with a large number of stakeholder groups, all with very different interests, competing with each other over different land uses. Employing participatory planning may be necessary in such circumstances in order to reduce power differentials and produce more equitable planning outcomes.

Such arguments have, however, largely failed to persuade tourism planners to adopt such techniques. This may be due to a lack of recognition of the potential of participatory approaches to enhance the planning process. Alternatively, it may be that most tourism planning authorities believe they lack the resources needed to implement such approaches (Hall, 2008). The latter seems more likely in that the use of participatory techniques in practical tourism planning remains rare, even then the authorities involved fully acknowledge their potential to enhance planning outcomes (Wearing et al., 2009a; Wearing et al., 2009b).

The preferred approach among tourism planners in most developed countries thus remains one of public consultation, rather than public participation. Public consultation implies merely seeking people's approval of plans that the authorities have already developed on their behalf; public participation, on the other hand, seeks to involve the public in the production of the plans. Another view emerging in the planning literature is, however, that "inside" knowledge of local resources and ecosystems can and should be used in making planning decisions (Schultz et al., 2007).

The aim of this paper is to assess of the potential of a participatory planning technique known as Volunteer-Employed Photography (VEP) to enhance the tourism planning process through its 
experimental application in St David's Peninsula, in the Pembrokeshire Coast National Park (PCNP), Wales (see Figure 1). This aim will be fulfilled by addressing three objectives.

*** Figure 1 near here $* * *$

The first objective is to assess the potential of VEP to generate data that are both appropriate and in sufficient volume to be useful in enhancing the tourism planning process. This will be examined through the application of VEP to tourism planning in St David's Peninsula. The second objective is to use VEP to attempt to identify points of similarity and difference in the opinions and experiences of locals and tourists with regard to the area's built and natural environments. The study will also assess the potential for the technique to help inform the situation analysis of a busy tourism area (Lavery, 2002). The third objective is to demonstrate the potential of VEP to assist in conflict resolution by identifying problems and generating potential solutions. Indeed, according to Wearing et al. (2009a), a necessary first step in conflict resolution is to identify the sources of the conflict.

In order to address these objectives, the theoretical arguments in favour of using VEP as a means of shaping tourism planning decisions are first investigated. The main findings of the research undertaken in St David's Peninsula are then presented and discussed. Finally, the appropriateness of the use of VEP as a tool to assist in tourism planning is presented and assessed. In this way, it is anticipated that the research will address a key gap in the literature: while there has been a shift towards participatory planning in tourism studies, accompanied by a shift towards the use of participant-generated images in social science research, it still remains for VEP to be fully tested as a tool for helping to inform and enhance tourism planning in practice.

\section{Use of photography in the social sciences and tourism research}

\subsection{Use of photography in social science research}

Social scientists have historically tended to use pictorial images in their writings merely for illustrative purposes and often simply to break the monotony of text (Prosser, 1998). As such, 
artwork and photographs have tended to be used essentially to supplement more traditional forms of research, rather than as data in themselves (Emmison \& Smith, 2000). Becker (1995) notes the sparse use of photography in sociological research and finds the slow development of the field of visual sociology astonishing. He attributes this to a widely held perception on the part of sociologists that the use of visual images is basically a ruse to persuade readers to accept poorly justified conclusions. He finds this particularly perplexing, since photographs are used routinely by natural scientists, including astronomers and biologists, who would consider it unthinkable to report on their research without the support of photographs, both as visual aids and as data in themselves.

Sociologists are not alone in their eschewal of visual methods. The most contentious issue in the use of visual data in the social sciences is that they best lend themselves to qualitative analysis, which is considered to be too subjective to be reliable. Harper (1988) counters this allegation by proposing that the researcher is fundamentally charged with the task of interpretation in any form of social research: the findings of social research are always passed through the researcher's personal filter as he or she is drawing conclusions from them. Prosser (1998) goes on to argue that photographs present the real world in the much same way as paintings, or indeed writing. Data embodied in any of these media require interpretation and this task must fall to the researcher. (Singhal \& Rattine-Flaherty, 2006), meanwhile, suggest that researchers should embrace the inherent subjectivity of the photograph for the very reason that it reflects the photographer's views, biases and knowledge: the very things they are seeking to understand. Indeed, it can be argued that sketches, paintings and photographs are simultaneously both technically and socially created (Singhal \& Rattine-Flaherty, 2006). The pen captures the world as it is perceived by the writer and, in just the same way, the camera captures what the eye sees (Jokinen \& Veijola, 2003). Taylor et al. (1995), meanwhile, argue that the camera lens and the human eye both represent the point of view of the person looking at something and taking a photograph of it.

While photographs have generally been under-used in tourism research, this is not to suggest that they have been entirely overlooked (Garrod, 2008). One of the major uses of photographs is in photo-elicitation. First described by Collier (1967), the method uses photographs that the 
researcher has either taken personally or collected from secondary sources as visual cues in questioning the research subject (Jenkins, 1999; Loeffler, 2004). It has long been argued that photo-elicitation can afford more and better insights into social phenomena (Banks, 2001; Harper, 2002; Matteucci, 2013). Even so, it is recognised that photo-elicitation cannot achieve maximum insight because of the filter that still exists between the intended meaning of the photograph when it was taken or collected by the researcher, and the participants' own understanding of the subject and its meaning in the context of their particular view of the world.

The solution to this dilemma is, to allow the research subjects to supply their own photographs (see Figure 2). This potential was first explored in the 1970s by two studies in which participants considered to be experts in a subject were given cameras and asked to photograph their experiences of it. These studies were the first to use participatory photography techniques. Traweek (1977) used VEP (which he called visitor-employed photography) to investigate visitors' perceptions of a river environment (Cherem \& Traweek, 1977; Traweek, 1977). In the same year, Ziller and Smith (1977) used participant-generated photographs to study participants perceptions of themselves. Since that time there have been more than 300 studies undertaken using what is essentially the VEP technique (Balomenou \& Garrod, forthcoming). One of the problems in trying to estimate the use of studies using VEP is that at least 34 terms have been proposed to denote the technique (Balomenou \& Garrod, forthcoming).

*** Figure 2 near here $* * *$

The major strength of VEP is that it embraces subjectivity, previously understood to be a disadvantage of photographic methods in social research. People's lives are best understood by those people themselves, and the researcher's role is to interpret their stories and opinions. Subjectivity is an inescapable feature of all social research, and VEP recognises this, working with it rather than against it. A number of further advantages of VEP are also identified in the literature. These include the empowerment afforded to participants to express their views (Rhodes et al., 2008; Armstrong, 2005; Boal, 1979; Hubbard, 1994), the ability to collect and study personalised, "verbatim” experiential accounts (Garrod, 2008; Luttrell, 2007), and greater enjoyment, and hence engagement, on the part of participants (Kaplan et al., 2007; Castleden et 
al., 2008) and researchers (Thompson et al., 2008). Negative features of VEP as a technique, meanwhile, tend to be associated with the administration of the research, including its tendency to be resource intensive (Bijoux and Myers, 2006, Kaplan et al., 2007) and the greater possibility of technical failure, for example due to equipment malfunction (Goodhart et al., 2006; Johnsen et al., 2008). Common ground among almost all commentators, however, is that such methods are under-utilised in social research (Garrod, 2007; MacKay \& Couldwell, 2002).

\subsection{Use of photographs in land-use planning and tourism planning}

Place perceptions have long been of interest to tourism researchers (Diedrich \& García-Buades, 2009; Mmopelwa et al., 2007; Poria et al., 2006). The tendency for tourism planners to be indifferent to the use of VEP techniques is therefore difficult to explain; even more so when aerial photography has been used to assist land-use planning for at least half a century (Marschner, 1950), especially today alongside remote-sensing technologies (Lagabrielle et al., 2010; Laumonier et al., 2010). Thus, while the use of photographic techniques has long been the norm in the "harder" scientific aspects of planning, it has only very rarely been used to examine to examine the "softer" social dimension of planning, as has long been recommended by social scientists (Beilin, 2005; Cherem \& Traweek, 1977; Stefano et al., 2005). This inconsistency is even more perplexing given that taking photographs is widely considered to be a definitive characteristic and social marker of being a tourist (Markwell, 2000; Urry, 2002). Indeed, the centrality of photography to the tourist experience, as well as its power to (mis)represent places, has inspired several studies of photographic practices and performance in the field of tourism (Crang, 1997; Markwell, 1997; Garlick, 2002; Stewart \& Floyd, 2004).

There are four main reasons why VEP is particularly relevant to tourism planning practice. The first is the shift towards public participation in land-use planning as a means of involving those affected by planning decisions in the making of those decisions (Adaman \& Devine, 2006; Kruger, 2007; Owen, 2002). The second is the potential for VEP to assist the understanding of tourism planning at a local level that, according to Hall (2008), is necessarily land-use oriented. The third is that community involvement in the tourism planning process can be considered essential for its success, as those who have personal experience of the area are best placed to 
determine what success should mean and how it should be pursued (Gunn \& Varr, 2002). The fourth is that aerial photography is currently used in land-use planning because it is considered the best way to map physical land use. By extension, therefore, tourists' and local residents' photographs may be a good way to 'map' their different perceptions and experiences of a tourism destination.

\subsection{The use of Volunteer-Employed Photography (VEP) in tourism research}

Haywood (1990, p.25) considered VEP to be highly appropriate to tourism planning, because photographs 'reveal something about us - how we see and interpret the world and the people and places in it, and all the meaning and associations we conjure up'. However, few researchers have used such methods (Naoi et al., 2011; MacKay \& Couldwell, 2002; Garrod, 2007). The first used of an approach similar to VEP was by Lynch in 1960, who asked his research participants to sketch detailed maps of the area he was examining (see Jutla, 2000). Lynch then used this data to investigate the "legibility" of that place, which Jutla (2000, p.408) defines as "the ability of the physical environment to communicate a clear image of itself'. The argument here is that while people may have their individual perceptions of a particular place, there should also be a "group image" on which people generally agree (Jutla, 2000). MacKay and Couldwell (2002, 2004) and Ruane et al. (2010), meanwhile, have used VEP to investigate tourism destination image. Traditionally, destination image has been measured using quantitative techniques. All three papers conclude, however, that VEP can be used as an alternative, qualitative technique of image assessment.

VEP studies have also been conducted in areas where land is used for recreational purposes (Dorwart et al., 2010; Dandy \& Van Der Wal, 2011; Cherem \& Driver, 1983). Managers and planners need to be able to visualise what the public sees or might see in a landscape before it is altered (Cherem \& Driver, 1983). Thus, VEP can be used to measure the relative importance of different landscape features (Taylor et al., 1995). It has been used successfully in planning recreational forests (Oku \& Fukamachi, 2006; Dandy \& Van Der Wal, 2011), landscape architecture (Chenoweth, 1984 ), national parks (Schuster et al., 2004), and rivers and other linear environments (Cherem \& Driver, 1983; Traweek, 1977; Dorwart et al., 2010). Chenoweth 
(1984), in particular, refers to the results of a VEP study that were used to influence public policy. Researchers who have conducted research on visitors' experiences also agree that photographs tell stories that can inform trip planners and designers, as well as destination managers and marketers, about visitors' preferences and expectations (Groves \& Timothy, 2001).

Such methods have also been used to illustrate differences between user groups in a tourism destination, although such studies are rare. One study examines the needs of different groups of visitors to a national park (Flick \& Taylor, 1998), while others examine local residents' and tourists' perceptions of a tourism destination (Garrod, 2007; Jutla, 2000; Hull \& Reveli, 1989). Jutla (2000) conducted a study of local residents and visitors of a heritage site, and concluded that there are no major differences in the ways people evaluate photos and actual sites. Jutla further argued that 'unless planners understand the various ingredients which come together to provide the essence of a place, they cannot modify it without risking the destruction of its valuable characteristics' (Jutla, 2000, p.405).

A few studies have used VEP to examine the local community perspective. Stedman et al. (2004, p.590), focus on "sense of place" and argue that photographic methods represent 'a logical progression in cumulative efforts to understand sense of place'. Kerstetter and Bricker (2009), meanwhile, investigate the meanings local residents attach to their local environment in an area where tourism is growing very fast. Brickell (2012) used "host-employed photography" to look at destination residents' perspectives of tourism development. Given that local communities have to live with the impacts of tourism, and that they have the expert knowledge of their area, there is a strong case for the use of VEP as a participatory tourism planning tool.

2.4.St David's Peninsula: the study area and its planning structures

The study area for this project is St David's Peninsula, which is situated in the northern part of the Pembrokeshire Coast National Park (PCNP) in Wales. One of Britain's 15 National Parks (National Parks, 2010), the PCNP was designated primarily for its coastal scenery and is the only 
coastal National Park in Britain. The PCNP also has some special characteristics that make it one of the most visited places in Wales.

Farming was the main income generator in the area for the best part of the twentieth century (Turvey, 2007). The development of the Milford Haven oil refinery also generated jobs for the local population. Today, the local economy is largely dependent on the tourism industry, which is highly visible as there is a ratio of 192 tourists to each local resident (Alwyn, personal communication). Informal interviews with residents suggest that more than half the houses in the settlement of St David's, which is the main population centre of the area, are holiday homes. Tourism is, however, highly seasonal, and visitors are more likely to stay in the area overnight during the spring and summer months (Trembath \& Tennstedt, 2008). The proportion of repeat visitors is very high, at over $80 \%$ (Trembath $\&$ Tennstedt, 2008). Jobs are perceived as low-paid and seasonal (Pembrokeshire Local Service Borad, 2012), and unemployment has increased remaining below the Welsh average with a faster than average rate of increase. (Pembrokeshire Local Service Borad, 2012).

Three of the 25 Local Planning Authorities (LPAs) in Wales are National Park Authorities (NPAs). Each has a National Park Management Plan and adheres to Welsh Government policy. In particular, LPAs must give regard to the 2008 Wales Spatial Plan in preparing their plans (Pycroft, 2010). There is, however, no body that tackles tourism planning as a whole in the PCNP. Land-use aspects of tourism are dealt by the NPA, whereas the County Council is responsible for the promotion and marketing of tourism opportunities. As such, tourism planning is not carried according to "ideal" processes, such as those recommended by writers such as Lavery (2002) or Hall (2008). If it is done at all, tourism planning is normally carried out within other planning frameworks, which means that it is undertaken either from the perspective of the local community or from the perspective of tourists. It is not common practice to systematically compare or combine the perspectives of these two stakeholder groups.

\section{Materials and methods}

3.1. Data collection methods: use of the VEP "triad" 
A number of researchers have suggested that in order to ensure that the photographs convey the meaning participants want them to convey, participatory photography exercises should always be accompanied by complementary techniques such as photo-diaries and personal interviews (Gemini \& Boccia-Artieri, 2007; OPENspace, 2005). Some researchers also note the importance of collecting as much information from participants as possible, so that it can be compared with data collected from other sources, thereby achieving a triangulation of data sources and methods as recommended by writers such as Decrop (1999). Accordingly, the study adopted a "VEP triad" (see Figure 3). Participants were asked to complete a questionnaire asking them for demographic data and some general attitudinal questions. They were then given cameras to take their photographs with. They were also given photo-diaries to note down the key features of each photograph (what they believed it to contain) and why they decided to take it (what they believed it to convey). The diaries were available in both English and Welsh.

*** Figure 3 near here $* * *$

An alternative to using diaries would have been to conduct interviews with participants after the photo-taking process had taken place (Jutla, 2000; Markwell, 1997). According to Bolger et al. (2003), however, diaries can be more useful because they record experiences in real time. Reis et al. (1994) suggest that this approach produces more meaningful data because it reduces the need for accurate recall of facts, feelings and thoughts on the part of participants. They also argue that the use of diaries facilitates the examination of accounted events and experiences in their actual context, allowing the researcher to collect a greater depth of information than would be possible using ex-post interviews.

The other component of the triad was a questionnaire, conducted with participants at the point of their recruitment. It was felt necessary to begin by establishing a rapport between the researcher and the participant, as the VEP method requires a substantial commitment on the part of participants (Bijoux and Myers, 2006; Haywood, 1990). A pilot study suggested that the survey was rather long (20 minutes on average), so the questionnaire was shortened by removing a some of the less directly relevant questions from the demographics section. 
Finally, one in-depth interview was held with a planner from the County Council, and another jointly with a PCNP planner and a park ranger. The purpose of these interviews was to gain a better understanding of the way in which tourism planning was implemented in the area. These were conducted after most of the participant photography had been completed, so that it was possible to show the planners some of the photographs that had been taken. The interviewees were asked their views on the usefulness of VEP in planning, and tourism planning specifically, in the PCNP context.

\subsection{Sampling}

Recruitment of tourists took place in August 2006, on every day of the week, including the August bank holiday weekend, for 12 hours each day, starting at eight in the morning. Following a discussion with the Tourist Information Centre (TIC) staff (Alwyn, personal communication), six sites that were popular with tourists were chosen. Twenty-five people agreed to participate in the survey from each site. Systematic random sampling was used to identify the participants. At each site, the first participant was chosen randomly, and following that, every fifth person passing in front of the researcher was approached and asked to participate. In the case of groups, the person whose next birthday was closest to the survey date was the next participant. The advantage of this method is that it is relatively simple and no other specific means of randomisation is needed (Altinay \& Paraskevas, 2008). Following the initial data collection and input, it emerged that the sample was statistically similar to the most recent PCNP visitor survey in terms of gender mix and balance of age groups.

A similar sampling process was followed for the recruitment of local community members. Sampling took place in September, as this was the period when the tourist flow starts to ease, and soon enough that local people have more free time available, but not so late that the local community will have forgotten their experiences of the tourist season. A mailing list, normally used for business advertising, was purchased for this purpose. One out of every five people was picked from the list, and the researcher visited their homes in person to request their participation. Further participants were recruited by writing to one in every five residents from 
the list. It generally proved more difficult and time-consuming to recruit the local residents than tourists but the rate of return of cameras and diaries was not statistically different between the two groups.

\subsection{Study implementation}

Three pilot surveys were undertaken in July and August 2006. The photo-diary, questionnaire and information letter to participants were adapted slightly after observations made by the researcher, and participants' feedback was also taken into account. A model photo and answer were also added in the diary to exemplify how it should be filled in. Participants were given a research pack comprising a folder, a coded disposable camera, a coded photo-diary, an explanatory letter, a pen and a bag in which to keep it all. The cost of each set, including the stamped addressed envelopes that were included in some packs, was approximately US\$11.

Participants were asked to take 12 photographs and informed that they could use up the rest of the film for their own photos, as a full set would be sent to them. This was intended as a small incentive to encourage them to complete the exercise and return the cameras and diaries. Local residents were asked to answer the following questions using their cameras and diaries: "What do you enjoy about living in the area?" and "What gives you a sense of place?" Visitors were asked the same questions adapted to their context: "Why have you chosen to visit this area?" and "What makes your visit enjoyable?" Participants were also asked to decide whether each photo was generally positive or negative in its intended message. For photographs with a positive message, they were then asked to complete a short section describing what would spoil the enjoyment of the area. For photos with negative messages, participants were asked to complete a section describing what would improve the area for them.

\subsection{Ethical considerations}

Approval from the University Ethics Committee was obtained. When the project started, there was little guidance for researchers involved in visual social research (Tolich, 2010). The statement of ethical practice from the British Sociological Association Visual Sociology Group 
was published later (Wiles et al., 2008). A common-sense approach was therefore taken to address the ethical issues. This was based on a review of the existing VEP literature, and took into consideration the UK Data Protection Act (1998) and the statement of ethical practice of the British Sociological Association (2002).

Three main issues were identified and addressed before the fieldwork was undertaken: copyright issues (Wiles et al., 2008), ensuring the participants' anonymity (Johnsen et al., 2008) and child safety (British Sociological Association, 2006). Participants were asked in advance for permission for the photos to be copyrighted to the University and were assured of their anonymity at all times.

\subsection{Data processing and analysis}

The dataset was analysed both qualitatively and quantitatively. The qualitative analysis involved drawing out themes from participants' responses to the tasks they were set. The themes comprised assessment of the assets of the case study area, identification of planning problems and suggested solutions, identification of contentious issues, and participants' thoughts on their experiences of being part of a VEP study. All of the photo-diaries and questionnaires were fully transcribed and 1,495 photographs were analysed in conjunction with their description in the diaries. Sub-categories of the original themes were thereby developed. Analysis proved to be an on-going, dynamic process as new sub-themes emerged following repeat reviews of the transcripts and photographs. Due to the size of the dataset, the NVivo qualitative software was used. In order to establish similarities and differences in locals' and tourists' responses, a series of chi-square tests was performed. These tests were usually between two observed and expected sets, so the Yates correction for continuity was employed.

\section{Results}

\subsection{Participant profile}


A $51.2 \%$ return rate from the local participants resulted in the return of 66 sets of cameras and survey booklets and 679 photos. A statistical comparison between the demographics of the project participants with the population of St David's and Solva Wards according to the census of 2001 (Office of National Statistics, 2003, 2004) suggested that the sample of local residents was representative of the population in terms of age, as presented in Table 1. However, the sample is not representative in terms of gender.

*** Table 1 near here $* * *$

A $76.5 \%$ return rate of the tourists' sample resulted in 114 full responses and 817 photographs. The final sample was well-balanced in relation to gender and age groups in comparison to the 2008 Visitor Survey (Horner, personal communication, which suggests confidence in the generalisability of the findings (see Table 2).

*** Table 2 near here

The main study findings were based on data collected from the questionnaires, photographs and diaries, which were grouped into five categories and entitled "What makes living and living in the area enjoyable?", "Problems and solutions", "What would enhance your experience of the area?", "What would spoil your experience of the area?" and "General comments". The accumulated dataset was very big and generated rich findings; however, this paper focuses on two particular questions - "What makes living in and visiting the area enjoyable?" and "Planning problems and solutions". These are investigated in detail to demonstrate the richness of the dataset, the depth of information that can be achieved, and similarities and differences in the views of the two stakeholder groups.

\subsection{Findings}

\subsubsection{What makes living in and visiting the area enjoyable?}


This question was intended to investigate how far VEP can contribute usefully in the situation analysis stage of the planning process. Participants in both user groups were invited to identify what they valued most about the area. Figure 4 illustrates the pattern of their responses.

\section{*** Figure 4 near here $* * *$}

The results of a chi-square test reveal no statistical difference between the groups in terms of location $\left(X^{2}=1.553, p=0.2\right)$ but tourists clearly feel more strongly than locals that further development will harm the area $\left(X^{2}=10.54, p=0.0\right)$. The quality of life was deemed more important by locals than tourists $\left(X^{2}=6.83, p=0.0\right)$.

All the local participants contributed to the category in their questionnaire entitled "What makes living in and visiting the area enjoyable?" Their responses were classified into four major categories, of which three were significantly more popular, as can be seen in Table 3. The photographs and diary comments were examined separately for each user group. Each comment in this part of the analysis corresponded directly to a photograph: everything the participants liked had a photographic representation and was situated in its own "locale" (Stedman et al., 2004).

*** Table 3 near here $* * *$

Table 3 shows that the broad themes commented on by the two groups were similar. However, locals went to much greater depth in their diaries, so an additional "other" category was devised for them. The tourists', in contrast, took more photographs but completed their diaries in less depth. Their photos and associated comments covered a smaller geographical area. The results also suggested that tourists showed less attachment to places and more attachment to activities and people.

Tourists and locals clearly approached answering the questionnaires with different mindsets. This is particularly clear in the theme of "things that make living or visiting the area enjoyable", where only two responses were given by both visitors and residents: namely the "Celtic Coaster" 
local bus service, and local arts and crafts. Chi-square tests were performed to identify similarities and differences in the importance of the area's assets for the two user groups, where similar categories could be formulated. The results of these tests indicate that that tourists have a greater appreciation that locals of the Celtic Coaster bus service $(\chi 2=4.04, p=0.04)$, and beautiful views and scenery $(\chi 2=5.06, p=0.02)$. The reverse was true of the sensuous qualities of the area $(\chi 2=21.74, \mathrm{p}=0.0)$, man-made landmarks $(\chi 2=18.67, \mathrm{p}=0.0)$ and the area's general natural assets $(\chi 2=4.23, \mathrm{p}=0.03)$. Meanwhile, no significant difference was found in the cases of local arts and crafts $(\chi 2=0.1, p=0.74)$; sea, bays and harbours $(\chi 2=, 0,33 \mathrm{p}=0.6)$; vegetation and wildlife $(\chi 2=2.38, p=0.12)$, and rock formations and geology $(\chi 2=3.51, p=0.06)$. A comparison of the importance of the assets of the area can be seen in Figure 5; tourists commented on far less aspects of the area compared to local participants.

*** Figure 5 near here $* * *$

Place attachment employs local knowledge and flags up places people feel strongly about. This is important information for planners (Stewart et al., 2003). A number of moving stories were recorded in the diaries, which illustrate the nature of place attachment and also highlights the need for the researcher to establish a rapport with participants (Miller \& Happell, 2006). For example, the caption of a photograph of St David's Cathedral by participant L9 (see Figure 6) reads: "The Cathedral. I used to sit by the bell tower looking down at the cathedral with my friends and have a chat and giggle. One of my friends has since passed away so they're treasurable memories". Other photographs illustrating residents" "sense of ownership" include pictures of their homes and the view from their homes, their workplaces and the houses they were born in.

*** Figure 6 near here $* * *$

\subsubsection{Problems and solutions}

Two specific questions asked were designed to reveal the participants' opinions on planning problems they experienced in the area and to collect their ideas on ways to address them: "Are 
there any aspects of the area you don't like?" and "How can the area be improved?" The responses are shown in Figure 7. A chi-square test showed that it is more likely for tourists than for local residents to say that there is nothing in the area they dislike $\left(X^{2}=13.42, p=0.0\right)$.

\section{$* * *$ Figure 7 near here $* * *$}

Aspects that the participants did not like are presented in Table 4. These results are consistent with Hall's (2008) observation that tourism planning issues are effectively land-use planning issues and relate to decisions made by the relevant authorities regarding the use of resources. Holidays homes and inflated house prices, as a combined category, was one of the biggest causes of dissatisfaction expressed by local residents. Overall, however, the causes of dissatisfaction were similar for the two user groups.

*** Table 4 near here $* * *$

Answers to "How can the area be improved?" are shown graphically in Figure 8. A chi-square test showed that tourists were more likely to suggest that the area should remain as it is compared to the local participants answering the question $\left(X^{2}=16.29, p=0.0\right)$. There were no significant differences between the two user groups in the rest of their answers.

*** Figure 8 near here $* * *$

A substantial majority of local residents (93.4\%) identified and discussed at least one problem using their cameras and diaries. The responses generated from questionnaires and photographs gave a very detailed account of their views. The local residents addressed a very wide range of issues, ranging from absence of battery-recycling facilities to highly politicised issues such as political pressures from the Countryside Council for Wales to close the Solva fishing grounds and the alleged attempts to turn the area into a "marine theme park". The problems raised were divided into 10 categories (see Figure 9).

\footnotetext{
** Figure 9 near here $* * *$
} 
Generally, the richness of the dataset suggests the participants enjoyed the task, but that visitors approached it in a more superficial manner than the locals. A total of 16 issues were identified that could be improved. A good example is transport planning, which was identified by 59 participants (of whom 33 were locals and 26 tourists), in 168 diary references (107 by locals and 61 by tourists). The findings suggest that there are significant differences in the way locals and tourists view the traffic in St David's Peninsula. The most frequently cited problem was the high volume of traffic. Tourists discussed traffic issues mainly with respect to St David's and Solva, the main settlements of the area, and in terms of access to Whitesands beach. Locals were more detailed in their approach, and a chi-square test showed that they were more worried about traffic issues compared to the tourists $\left(X^{2}=6.04, p=0.01\right)$. Lower Solva and Upper Solva are linked by the village high street, where the church, shops and school are located. This road is very narrow, and especially in the summer it is often impossible to drive through. Meanwhile, both locals and tourists in St David's noted that the main street is also a through road that connects Haverfordwest to Fishguard. During the summer, with the influx of tourists and coaches stopping in the middle of the street, traffic can come to a standstill. Participants also mentioned that roads are becoming more dangerous as they were not designed for today's volumes of traffic. In particular, the large four-wheel-drive vehicles (referred to as 'Chelsea tractors' in more than one occasion) that can frequently been seen in the narrow Pembrokeshire lanes are considered an increasing safety hazard to cyclists, walkers and even drivers of smaller cars. The issues raised and suggested solutions can be seen in Table 5 .

*** Table 5 near here $* * *$

\section{Discussion}

Dollinger (2001) proposes that while techniques using VEP do not offer quantitative precision, they do offer the opportunity to generate rich qualitative data (see also Dollinger and Clancy 1993; Germain 2004). Perry (2006), meanwhile, suggests that the power of images, combined with the empowerment of participants, offers substantial depth of insight and explanation. The present study confirms both these propositions. The VEP technique is able to generate a multi- 
dimensional and multi-layered dataset, which has considerable potential for use in further investigations. A multi-dimensional dataset was created through the use of the VEP "triad" and then layered using the NVivo8 qualitative data analysis software (Bringer et al., 2004).

While Lavery (2002) and Hall (2008) describe situation analysis differently, they agree that it is an essential step in tourism planning. In this study, participants were asked what they considered to be the principal assets of the area, and they were asked to take photographs of these assets and discuss them in their diaries. This generated a substantial dataset, including documentary photographs, which would be very useful as an input to this stage of the tourism planning process (Castleden et al., 2008; Chenoweth, 1984; Dakin, 2003; Stefano et al., 2005). The data also highlight differences in place perceptions according to user group, age group, gender, attitudes to development, and so on, which could again be useful information for planners.

An area's natural assets are considered by planners to be of prime importance for the enjoyment of the area for locals and tourists alike. However, the findings of this study suggest that the aesthetic qualities of the area are likely to be more important to local residents than visitors to the area. Local residents, as one might expect, tend to demonstrate stronger place attachment than visitors (Stedman et al., 2004). VEP is clearly a good way of capturing these values. Indeed, Stewart et al. (2003) argue that VEP can be a good way of highlighting places that people feel strongly about: places that planners can and should then focus on. Tourists were evidently less "emotionally" attached to the area in this study. They nevertheless offered many photographs with a strong emotional element, usually depicting their family or pets. A number of photographs that were captured here would not have been taken had the researcher been present (OPENspace, 2005). It can therefore be argued that VEP is able to access and illuminate opinions that other techniques may not be able to: information that planners would doubtless find valuable.

The analysis also demonstrated vital differences in the ways locals and tourists see, understand and experience the area. While the actual photographs taken by members of the two groups often appeared similar, the reasons for taking the photo could differ substantially. An example is two photos of Cross Square and their descriptions (Figures 10 and 11), the first taken by a local resident and the second by a tourist. At first sight they look similar but their captions 
demonstrate a difference in the way the same place is experienced by a member of the local community and a tourist.

*** Figure 10 near here $* * *$

*** Figure 11 near here $* * *$

The caption accompanying the first photograph reads: "This ancient stone cross is a focal point for the community - the St David's Day events are held here and meeting for the 'coming together' after tragic events such as the tsunami". The caption under the second reads: "It's a good thing, to obtain the old documents of the former societies, which lived in this country. Especially it's a good thing, to obtain the Celtic roots of the Welsh culture". Cross Square is is depicted by the local resident as very much a part of contemporary, everyday life: as confirmed by the large number of local resident participants also photographed it and made similar comments. The tourist, in contrast, approached Cross Square from a heritage perspective, viewing it as a relic from the past.

The potential of VEP to resolve conflict by identifying problems and issues experienced by both user groups is also demonstrated in this study. The planners who were interviewed (Horner, personal communication; Middleton \& Lees, personal communication) both found that photographs can raise very powerful responses and can be very useful as evidence to influence planning decisions: a view that accords with Chenoweth (1984). Stedman et al. (2004), meanwhile, suggest that photographs allow a more locale-specific analysis of the area. The present study clearly supports these propositions, particularly in respect of the local problems identified by the study participants.

Participants' overall assessment of VEP was positive. They noted strengths of the technique that were similar to those suggested in the literature, and considered participation an excellent opportunity to express their views (Armstrong, 2005; Rhodes et al., 2008). Many participants also admitted that the photo-taking process made them "stop and think" (Radley \& Taylor, 2003; Foster-Fishman et al., 2005; Aubeeluck \& Buchanan, 2006; Noland, 2006). The negative 
comments, meanwhile, mainly concerned logistics such as participants thinking that 12 photos were too many or not enough, confusion over the numbering of the photos (as the first one had already been taken by the researcher to identify the film) and the technical limitations of the disposable camera. Indeed, several participants complained that the camera was unable to capture the shots they would have liked to take. Judging from the average number of photos captured (11.13 per local participants, 10.47 per tourist), asking participants to take 12 photographs could be considered viable for this type of project. Unfortunately it is impossible to compare this to the literature as very few papers include data of this type (Balomenou \& Garrod, forthcoming).

The difficulty with the numbering is something that can easily be avoided in future research. The comment on the technical capabilities of disposable cameras is very interesting. Although digital photography might have been easier and quicker, and the quality of the photographs may have been better (Hanieh \& Walker, 2007), participants would have been able to delete or manipulate the photographs. This could have detracted from the desired spontaneity and actual experiences of the exercise. Finally, it was also suggested that it was tricky trying to walk around taking photographs while also using a pen and paper to write the diary. Voice recording could be an option in future research: indeed, there are now cameras on the market that include this function. However, the principle should be that the voice recording should take place at the same time as the experience, so that participants' comments and justifications are captured in real time.

Finally, when the County Council and National Park planners and ranger were interviewed, they were asked to comment on the potential of VEP to promote participation in the tourism planning process. Again, their comments were in line with those in VEP literature supporting further use of VEP. Positive comments include the potential to understand where tourists have actually been during their holiday. Photographs can serve as evidence in planning decision-making (Berman et al., 2001; Carlson et al., 2006; López et al., 2005), often having a greater impact than written text. It was also suggested that VEP could demonstrate what works and what does not work, unlike a table of statistics. In other words, it is considered possible that VEP can effectively be used to influence public policy (Chenoweth, 1984; Horner, personal communication), and to identify planning issues (Middleton \& Lees, personal communication). With regard to the latter 
proposition, Phil Lees suggested that "it is a sort of a planning for real thing, isn't it? Walking around your village, what you like, vernacular architecture, what you don't like." It was felt that with appropriate parameters in place that would make the research more specific, VEP could actually help in the planning process (Middleton \& Lees, personal communication).

On the other hand, this study was considered by the interviewees to be rather too generic, touching on issues from dog faeces to holiday homes. Sarah Middleton suggested that to have a photograph of something, it has to be there already, while in planning "we are talking about concepts sometimes". However, it can be argued that VEP can be used to evaluate the landscape values prior to any development. An issue that everybody raised, however, was that of staff time, as VEP was considered time-consuming. This limitation has already been identified in the literature (Damico, 1985; Haywood, 1990; Kaplan et al., 2007). The interviewees also argued that representative sampling should be ensured if the study was to assist planning, as this would support generalisation of the findings.

\section{Conclusions and recommendations}

In this study, VEP was used in a busy tourist area to explore how well it can be used to record different people's views and experiences in real time. It was used to record planning problems and proposed solutions, positive and negative aspects of the area, and suggestions for how the participants' experiences of it could be improved. The study set out to test the potential of VEP to inform tourism planning decisions and the findings confirm this potential. Figure 12 shows how VEP can supplement Hall's (2008) model of the tourism planning process.

*** Figure 12 near here ***

All the positive aspects of VEP suggested in the literature were observed in this study. More importantly, the use of photographs and text proved to be a powerful combination that, in addition to vividly portraying participants' opinions and perspectives on their experiences, can affect the participant in a very emotive way. Photos in combination with text can evoke strong feelings, which transport the viewers to places where they are invited to feel sadness about the 
loss of a loved one, contentment in the presence of the beauty of nature, or frustration when they see a wheelchair user unable to access the pavement because of badly parked cars, a result of the lack of sufficient parking spaces to cater for both locals and tourists during the high tourism season.

\subsection{Reflections on limitations}

Two limitations are clear from this research. First, despite the richness of the dataset, which is clearly an asset of VEP (Aubeeluck \& Buchanan, 2006; Miller \& Happell, 2006), collecting the data was very time-consuming for the researcher. Thus, while VEP may be very rewarding in terms of results, it also tends to be resource-intensive. This may not be a problem for academic researchers but it must surely represent a major constraint to its adoption by tourism planning authorities. Undertaking VEP in a practical context would probably require a team of researchers, as well as administrative help at various stages of the process, if the technique is to achieve its potential. Secondly, with visual sociology being such a fragmented field of study, and with so many terms used to describe the VEP family of techniques, there are almost certainly more studies of this kind that have not been identified in this paper. However, it is hoped that due to the more extensive use of relevant techniques in recent years, the use of VEP in earlier studies can be traced if the reader wishes to.

\subsection{Recommendations for future research}

Three lines of further inquiry are suggested: improving the technique, planning in national parks, and the visual dimension of planning. To improve the VEP technique, further research needs to be undertaken in order to establish best-practice guidelines for the different fields in which it is to be used. Further research is also needed into complementary techniques, the relative benefits of different types of camera, and the relative merits of different methods of analysis. It does not seem likely that strict guidelines for the use of VEP will ever be established; nor would that indeed be desirable. However, the existence of broad guidelines would help the method to evolve. To develop these guidelines, VEP needs to be attempted and tested in a variety of different ways and in a multitude of fields. 
The most important recommendation for tourism planning in the PCNP relates to the relatively weak channels of communication that exist between planners and local residents, between planners and tourists, and between planners in the NPA and the County Council. Given the importance of tourism in the local economy and its potential impact on the local community and the natural environment, tourism planning should be considered a priority, even if it is not the responsibility of a single authority. Planning is, however, currently undertaken in a highly fragmented fashion. Ways need to be found, therefore, for planning processes to be consolidated and thereby made more effective. Currently, certain tourism planning issues are only addressed by the operational dynamics of the market. This does not guarantee sensible or sustainable outcomes. More extensive and intensive participation by local residents and tourists in the planning process should therefore be a priority for both the NPA and the County Council.

\section{References}

Adaman, F. \& Devine, P. (2006). The promise of participatory planning: a rejoinder to Hodgson. Economy and Society, 35, 141-147.

Altinay, L. \& Paraskevas, A. (2008). Planning research in hospitality and tourism. Oxford and Burlington: Butterworth-Heinemann.

Armstrong, K. B. (2005). Autophotography in adult education: building creative communities for social justice and democratic education. New Directions for Adult and Continuing Education, 2005, 33-44.

Aubeeluck, A. \& Buchanan, H. (2006). Capturing the Huntington's disease spousal carer experience: a preliminary investigation using the 'photovoice' method. Dementia, 5, 95-116.

Balomenou, N. \& Garrod, B. (forthcoming). A Review of Participant-Generated Image Research in the Social Sciences. 
Banks, M. (2001). Visual methods in social research. London: Sage.

Becker, H. S. (1995). Visual sociology, documentary photography, and photojournalism: it's (almost) all a matter of context. Visual Sociology, 10, 5-14.

Beilin, R. (2005). Photo-elicitation and the agricultural landscape: 'seeing' and 'telling' about farming, community and place. Visual Studies, 20, 56-68.

Berman, H., Ford-Gilboe, M., Moutrey, B. \& Cekic, S. (2001). Portraits of pain and promise: a photographic study of Bosnian youth. Canadian Journal of Nursing Research, 32, 21-41.

Bijoux, D. \& Myers, J. (2006). Interviews, solicited diaries and photography: 'new' ways of accessing everyday experiences of place. Graduate Journal of Asia-Pacific Studies, 4, 44-64.

Boal, A. (1979). Theater of the oppressed. London: Pluto Press.

Bolger, N., Davis, A. \& Rafaeli, E. (2003). Diary methods: capturing life as it is lived. Annual Review of Psychology, 54, 579-616.

Brickell, K. (2012). Visual Critiques of Tourist Development: host-Employed Photography in Vietnam. Tourism Geographies, 14, 98-116.

Bringer, J. D., Johnston, L. H. \& Brackenridge, C. H. (2004). Maximizing transparency in a doctoral thesis: the complexities of writing about the use of QSR*NVIVO within a grounded theory study. Qualitative Research, 4, 247-265.

British Sociological Association (2002). Statement of ethical practice for the BSA. Durham: British Sociological Association.

British Sociological Association (2006). Visual Sociology Group's statement of ethical practice. [Online]. Available: www.visualsociology.org.uk/about/ethical_statement.php. Accessed 1.25.2013. 
Carlson, E. D., Engebretson, J. \& Chamberlain, R. M. (2006). Photovoice as a social process of critical consciousness. Qualitative Health Research, 16, 836-852.

Castleden, H., Garvin, T. \& First Nation, H.-A.-A. (2008). Modifying photovoice for community-based participatory indigenous research. Social Science \& Medicine, 66, 1393-1405.

Chenoweth, R. (1984). Visitor employed photography: a potential tool for landscape architecture. Landscape Journal, 3, 136-143.

Cherem, G. \& Driver, B. (1983). Visitor employed photography: a technique to measure common perceptions of natural environments. Journal of Leisure Research, 15, 65-83.

Cherem, G. J. \& Traweek, D. E. (1977). Visitor employed photography: a tool for interpretive planning on river environments. In Proceedings of River Recreation Management and Research Symposium, 1977 (pp, 236-244). USDA Forest Services

Collier, J. J. (1967). Visual anthropology: photography as a research method, New York: Holt, Rinehart \& Winston.

Crang, M. (1997). Picturing practices: research through the tourist gaze. Progress in Human Geography, 21, 359-373.

Dakin, S. (2003). There's more to landscape than meets the eye: towards inclusive landscape assessment in resource and environmental management. Canadian Geographer, 47, 185-200.

Damico, S. B. (1985). The two worlds of school: differences in the photographs of black and white adolescents. The Urban Review, 17, 210-222. 
Dandy, N. \& Van Der Wal, R. (2011). Shared appreciation of woodland landscapes by land management professionals and lay people: an exploration through field-based interactive photoelicitation. Landscape and Urban Planning, 102, 43-53.

Data Protection Act (1998). The National Archives.

Decrop, A. (1999). Triangulation in qualitative tourism research. Tourism Management, 20, 157161.

Diedrich, A. \& García-Buades, E. (2009). Local perceptions of tourism as indicators of destination decline. Tourism Management, 30, 512-521.

Dollinger, S. J. (2001). Religious identity: an autophotographic study. International Journal for the Psychology of Religion, 11, 71-92.

Dollinger, S. J. \& Clancy, S. M. (1993). Identity, self, and personality: glimpses through the autophotographic eye. Journal of Personality and Social Psychology, 64, 1064-1071.

Dorwart, C. E., Moore, R. L. \& Leung, Y.-F. (2010). Visitors' perceptions of a trail environment and effects on experiences: a model for nature-based recreation experiences. Leisure Sciences, $32,33-54$.

Emmison, M. \& Smith, P. (2000). Current trends in visual research. London: Sage.

Flick, S. \& Taylor, J. (1998). Attitudes of backpackers and casual day visitors in Rocky Mountain National Park. Park Science, 18, 18-20.

Foster-Fishman, P., Nowell, B., Deacon, Z., Nievar, M. \& McCann, P. (2005). Using methods that matter: the impact of reflection, dialogue, and voice. American Journal of Community Psychology, 36, 275-291. 
Garlick, S. (2002). Revealing the unseen: tourism, art and photography. Cultural Studies, 16, 289-305.

Garrod, B. (2007). A snapshot into the past: the utility of volunteer-employed photography in planning and managing heritage tourism. Journal of Heritage Tourism, 2, 14-33.

Garrod, B. (2008). Exploring place perception a photo-based analysis. Annals of Tourism Research, 35, 381-401.

Gemini, L. \& Boccia-Artieri, G. (2007). Images of beauty and family: Contemprary Imagery at Aqufan. Conference paper. Glancing, glimpsing and gazing: tourists and tourism in a visual world. Eastbourne, UK.

Germain, R. (2004). An exploratory study using cameras and Talking Mats to access the views of young people with learning disabilities on their out-of-school activities. British Journal of Learning Disabilities, 32, 170-174.

Getz, D. \& Jamal, T. B. (1994). The environment-community symbiosis: a case for collaborative tourism planning. Journal of Sustainable Tourism, 2, 152-173.

Goodhart, F. W., Hsu, J., Baek, J. H., Coleman, A. L., Maeresca, F. M. \& Miller, M. B. (2006). A view through a different lens: photovoice as a tool for student advocacy. Journal of American College Health, 55, 53-56.

Google Maps. (2013). Pembrokeshire Coast National Park map [Online]. Available: https://maps.google.co.uk/maps. Accessed 1.25.2013.

Groves, D. L. \& Timothy, D. J. (2001). Photographic techniques and the measurement of impact and importance attributes on trip design: a case study. Loisir et Société, 24, 311-317. 
Gunn, C. A. \& Varr, T. (2002). Tourism planning: basics, concepts, cases. New York: Routledge.

Hall, C. M. (2008). Tourism planning: policies, processes and relationships. Harlow: Pearson.

Hanieh, E. \& Walker, B. M. (2007). Photography as a measure of constricted construing: the experience of depression through a camera. Journal of Constructivist Psychology, 20, 183-200.

Harper, D. (1988). Visual sociology: expanding sociological vision. The American Sociologist, $19,54-70$.

Harper, D. (2002). Talking about pictures: a case for photo elicitation. Visual Studies, 17, 13-26.

Haywood, K. M. (1990). Visitor-employed photography: an urban visit assessment. Journal of Travel Research, 29, 25-29.

Hubbard, J. (1994). Shooting back from the reservation: a photographic view of life by Native American youth. New York: New Press.

Hull IV, R. B. \& Reveli, G. R. B. (1989). Cross-cultural comparison of landscape scenic beauty evaluations: A case study in Bali. Journal of Environmental Psychology, 9, 177-191.

Jamal, T. B. \& Getz, D. (1995). Collaboration theory and community tourism planning. Annals of Tourism Research, 22, 186-204.

Jenkins, O. H. (1999). Understanding and measuring tourist destination images. International Journal of Tourism Research, 1, 1-15.

Johnsen, S., May, J. \& Cloke, P. (2008). Imag(in)ing homeless places: using auto-photography to (re)examine the geographies of homelessness. Area, 40, 194-207. 
Jokinen, E. \& Veijola, S. (2003). Visual culture and tourism. Oxford: Berg.

Jutla, R. S. (2000). Visual image of the city: tourists' versus residents' perception of Simla, a hill station in northern India. Tourism Geographies, 2, 404-420.

Kaplan, I., Lewis, I. \& Mumba, P. (2007). Picturing global educational inclusion? Looking and thinking across students' photographs from the UK, Zambia and Indonesia. Journal of Research in Special Educational Needs, 7, 23-35.

Kerstetter, D. \& Bricker, K. (2009). Exploring Fijian's sense of place after exposure to tourism development. Journal of Sustainable Tourism, 17, 691-708.

Kruger, M. H. (2007). Community-based crime control in Cuba. Contemporary Justice Review: Issues in Criminal, Social, and Restorative Justice, 10, 101-114.

Lagabrielle, E., Botta, A., Daré, W., David, D., Aubert, S. \& Fabricus, C. (2010). Modelling with stakeholders to integrate biodiversity into land-use planning: lessons learned in Réunion Island (Western Indian Ocean). Environmental Modelling \& Software, 25, 1413-1427.

Laumonier, Y., Uryu, Y., Stüwe, M., Budiman, A., Setiabudi, B. \& Hadian, O. (2010). Ecofloristic sectors and deforestation threats in Sumatra: identifying new conservation area network priorities for ecosystem-based land use planning. Biodiversity and Conservation, 19, 1153-1174.

Lavery, P. (2002). Tourism planning. Huntington: ELM.

Loeffler, T. A. (2004). A photo elicitation study of the meanings of outdoor adventure experiences. Journal of Leisure Research, 36, 536-556.

López, E. D. S., Eng, E., Randall-David, E. \& Robinson, N. (2005). Quality-of-life concerns of African-American breast cancer survivors within rural North Carolina: blending the techniques of photovoice and grounded theory. Qualitative Health Research, 15, 99-115. 
Luttrell, W. (2007). Sometimes, pictures speak louder than words. Usable knowledge. Harvard Graduate School of Education [Online] Available http://www.uknow.gse.harvard.edu/decisions/DD2-3-507.html. Accessed 5.25.2007.

MacKay, K. J. \& Couldwell, C. (2002). Seeing our sites through our visitors' eyes: investigating visitors' images of Motherwell Homestead National Historic Site. Research Links: A Forum for Natural, Cultural and Social Studies, Volume 11.

MacKay, K. J. \& Couldwell, C. M. (2004). Using visitor-employed photography to investigate destination image. Journal of Travel Research, 42, 390-396.

Markwell, K. W. (1997). Dimensions of photography in a nature-based tour. Annals of Tourism Research, 24, 131-155.

Markwell, K. W. (2000). Seeing is believing is knowing: towards a critique of pure vision: a rejoinder. Australian Geographical Studies, 38, 341-343.

Marschner, F. J. (1950). Major land uses in the United States, 1: 5,000,000. U.S. Deptartment of Agriculture, Agricultural Research Service.

Matteucci, X. (2013). Photo elicitation: Exploring toiurist experiences with researcher-found images. Tourism Management, 35, 190-197

Miller, G. \& Happell, B. (2006). Talking about hope: the use of participant photography. Issues in Mental Health Nursing, 27, 1051-1065.

Mmopelwa, G., Kgathi, D. L. \& Molefhe, L. (2007). Tourists' perceptions and their willingness to pay for park fees: a case study of self-drive tourists and clients for mobile tour operators in Moremi Game Reserve, Botswana. Tourism Management, 28, 1044-1056. 
Naoi, T., Yamada, T., Iijima, S. \& Kumazaaw, T. 2011. Applying the caption evaluation method to studies of visitors evaluation of historical districts. Tourism Management, 32, 1061-1074.

National Parks (2010). National Parks, Britain's breathing spaces. [Online] Available http://www.nationalparks.gov.uk/. Accessed 25.1.2013.

Noland, C. M. (2006). Auto-photography as research practice: identity and self-esteem research. Journal of Research Practice, 2, M1.

Office of National Statistics (2003). Neighbourhood statistics, information on: St. David's and the Cathedral Close community (parish). Office of National Statistics.

Office of National Statistics (2004). Neighbourhood statistics, parish headcounts, Solva community. Office of National Statistics.

Oku, H. \& Fukamachi, K. (2006). The differences in scenic perception of forest visitors through their attributes and recreational activity. Landscape and Urban Planning, 75, 34-42.

OPENspace (2005). Evaluation of visitor experience at Ynyslas/Dyfi National Nature Reserve. Final Report. Countryside Council for Wales, March.

Owen, S. (2002). From village design statements to parish plans: some pointers towards community decision making in the planning system in England. Planning Practice and Research, 17, 81-89.

Pembrokeshire Local Service Board (2012). Draft Pembrokeshire Simple Integrated Plan 20132018. [Online] Available http://www.pembrokeshire.gov.uk/content.asp?nav=646,101,126,1712. Accessed 1.25.2013.

Perry, B. 2006. Using photographic images as an interactive online teaching strategy. The Internet and Higher Education, 9, 229-240. 
Poria, Y., Reichel, A. \& Biran, A. (2006). Heritage site perceptions and motivations to visit. Journal of Travel Research, 44, 318-326.

Prosser, J. (1998). Image-based research; a sourcebook for qualitative researchers. London: Falmer.

Pycroft, G. (2010). Sustainability committee planning inquiry [Online]. Association of National Park Authorities, Cardiff. [Online] Available:

http://www.nationalparks.gov.uk/sustainability_committee_planning_inquiry.pdf. Accessed 8.23.2010.

Radley, A. \& Taylor, D. (2003). Images of recovery: a photo-elicitation study on the hospital ward. Qualitative Health Research, 13, 77-99.

Reed, M. G. (1997). Power relations and community-based tourism planning. Annals of Tourism Research, 24, 566-591.

Reis, H. T., Erber, R. \& Gilmour. (eds.) (1994). Domains of experience: investigating relationship processes from three perspectives. Hillsdale: Erlbaum.

Rhodes, S. D., Hergenrather, K. C., Wilkin, A. M. \& Jolly, C. (2008). Visions and voices: indigent persons living with HIV in the southern United States use photovoice to create knowledge, develop partnerships, and take action. Health Promotion Practice, 9, 159-169.

Ruane, S. T., Quinn, B., Spencer, C. \& Flanagan, S. (2010). Reporting on the utility of volunteer employed photography as part of a multi-method approach to explore Ireland's destination image. 6th Annual Conference on Tourism and Hospitality Research. Shannon. 
Schultz, L., Folke, C. \& Olsson, P. (2007). Enhancing ecosystem management through socialecological inventories: lessons from Kristianstads Vattenrike, Sweden. Environmental Conservation, 34, 140-152.

Schuster, E., Johnson, S. S. \& Taylor, J. G. 2004. Wilderness experience in Rocky Mountain National Park 2002: Report to RMNP. U.S. Geological Survey, No.445.

Simmons, D. G. (1994). Community participation in tourism planning. Tourism Management, 15, 98-108.

Singhal, A. \& Rattine-Flaherty, E. (2006). Pencils and photos as tools of communicative research and praxis: analyzing Minga Perú's quest for social justice in the Amazon. International Communication Gazette, 68, 313-330.

Spencer, D. M. (2010). Facilitating public participation in tourism planning on American Indian reservations: a case study involving the nominal group technique. Tourism Management, 31 , 684-690.

Stedman, R., Beckley, T., Wallace, S. \& Ambard, M. (2004). A picture and 1000 words: using resident-employed photography to understand attachment to high amenity places. Journal of Leisure Research, 36, 580-606.

Stefano, L. A., Stilwell, C., Morris, C. \& Hendriks, S. L. (2005). 'As I see it': small-scale commercial organic farmers use photography to record farm system changes. Ingede, the Journal of African Scholarship, 1, Online.

Stewart, W. P. \& Floyd, M. F. (2004). Visualizing leisure. Journal of Leisure Research, 36, 445460.

Stewart, W. P., Liebert, D. \& Larkin, K. W. (2003). Community identities as visions for landscape change. Landscape and Urban Planning, 69, 315-334. 
Taylor, J. G., Czarnowski, K. J., Sexton, N. R. \& Flick, S. (1995). The Importance of water to Rocky Mountain National Park visitors: an adaptation of visitor-employed photography to natural resources management. Journal of Applied Recreation Research, 20, 61-85.

Thompson, N. C., Hunter, E. E., Murray, L., Ninci, L., Rolfs, E. M. \& Pallikkathayil, L. (2008). The experience of living with chronic mental illness: a photovoice study. Perspectives in Psychiatric Care, 44, 14-24.

Tolich, M. (2010). A critique of current practice: ten foundational guidelines for autoethnographers. Qualitative Health Research, 20, 1599-1610.

Traweek, D. E. (1977). Visitor employed photography on the Huron River: a tool for interpretive planning. $\mathrm{PhD}$, Ohio State University.

Trembath, C. \& Tennstedt, K. (2008). Pembrokeshire Visitor Survey 2007/2008 Final Report for Pembrokeshire Cost National Park. York: QA Research.

Turvey, R. (2007). Pembrokeshire: the concise history. Cardiff: University of Wales Press.

Urry, J. (2002). The tourist gaze. London: Sage.

Wearing, S., Grabowski, S., Chatterton, P. \& Ponting, J. (2009a. Participatory planning for ecotrekking on a potential World Heritage site: the communities of the Kokoda Track. Pacific Economic Bulletin, 24, 101-117.

Wearing, S. L., Wearing, M. \& McDonald, M. (2009b). Understanding local power and interactional processes in sustainable tourism: exploring village-tour operator relations on the Kokoda Track, Papua New Guinea. Journal of Sustainable Tourism, 18, 61-76.

Wikipedia (2013). Wales Map [Online]. Available:

http://en.wikipedia.org/wiki/File:Wales_Pembrokeshire_locator_map.svg. Accesses 1.25.2013. 
Wiles, R., Prosser, J., Bagnoli, A., Clark, A., Davies, K., Holland, S. \& Renold, E. (2008). Visual ethics: ethical issues in visual research. Swindon: ESRC.

Ziller, C. \& Smith, E. (1977). A phenomenological utilisation of photographs. Journal of Phenomenological Psychology, 7, 172-182. 
Table 1: Demographics of local resident participants compared to the 2001 census

\begin{tabular}{|c|c|c|c|c|c|}
\hline & $\begin{array}{l}\text { St David's } \\
\text { Ward }\end{array}$ & $\begin{array}{l}\text { Solva } \\
\text { Ward }\end{array}$ & Total & $\begin{array}{l}\text { Tourism planning } \\
\text { project }\end{array}$ & $X^{2}$ test result \\
\hline $\begin{array}{l}\text { All } \\
\text { people }\end{array}$ & 1797 & 1420 & 3217 & 61 & \\
\hline Males & 849 & 722 & $1571(48.8 \%)$ & $21(34.4 \%)$ & \multirow{2}{*}{$\begin{array}{l}X^{2}=4.95 \\
p=0.25 \\
\text { Significant } \\
\text { difference }\end{array}$} \\
\hline Females & 948 & 698 & $1646(51.2 \%)$ & $40(65.6 \%)$ & \\
\hline $16-29$ & 236 & 242 & 478 & 8 & \multirow{5}{*}{$\begin{array}{l}X^{2}=3.069 \\
p=0.54 \\
\text { No significant } \\
\text { difference }\end{array}$} \\
\hline $30-44$ & 302 & 235 & 537 & 9 & \\
\hline $45-59$ & 422 & 319 & 741 & 20 & \\
\hline $60-74$ & 320 & 232 & 552 & 16 & \\
\hline $75+$ & 227 & 138 & 365 & 8 & \\
\hline
\end{tabular}


Table 2: Demographics of tourist participants compared to the 2008 visitor survey

\begin{tabular}{|c|c|c|c|}
\hline Tourist participants & Tourism planning project & Visitor survey & $X^{2}$ test result \\
\hline Men & $50.6 \%$ & $50.8 \%$ & \multirow{2}{*}{$\begin{array}{l}X^{2}=0.001 \\
p=0.974 \\
\text { No significant } \\
\text { difference }\end{array}$} \\
\hline Women & $49.4 \%$ & $49.2 \%$ & \\
\hline $18-24$ year olds & 2 & 50 & \multirow{6}{*}{$\begin{array}{l}X^{2}=1.996 \\
p=0.84 \\
\text { No significant } \\
\text { difference }\end{array}$} \\
\hline $25-34$ year olds & 13 & 158 & \\
\hline $35-44$ year olds & 16 & 236 & \\
\hline 45-54 year olds & 19 & 240 & \\
\hline 55-64 year olds & 16 & 237 & \\
\hline $65+$ year olds & 12 & 222 & \\
\hline
\end{tabular}


Table 3: What makes living in and visiting the area enjoyable?

\begin{tabular}{|l|l|}
\hline What makes living in the area enjoyable? & What makes visiting the area enjoyable? \\
\hline Important places for local community members 61 & Important places for tourists 77 \\
\hline Local pride 59 & \\
\hline Things that make life enjoyable 48 & Things that make visiting the area enjoyable 71 \\
\hline People 9 & People 25 \\
\hline Other 8 & \\
\hline
\end{tabular}


Table 4: Aspects of the area participants do not like

\begin{tabular}{|l|l|}
\hline Aspects of the area local participants do not like & Aspects of the area tourist participants do not like \\
\hline Holiday homes (8) & Dog mess (3) \\
\hline Heavy traffic (6) & Caravan parks (3) \\
\hline Insufficient parking (6) & Too many cars(3) \\
\hline Inflated house prices (6) & Oil refinery (3) \\
\hline Too many tourists (6) & Too many tourists (2) \\
\hline $\begin{array}{l}\text { Lack of funding to cover the needs of the community } \\
(3)\end{array}$ & Bad weather (2) \\
\hline Seasonal work (3) & Narrow roads (2) \\
\hline $\begin{array}{l}\text { No entertainment alternatives (3) } \\
\text { Lack of local produce, lack of parking, second homes, small } \\
\text { roads, bad meals, traffic wardens, lack of disabled access } \\
\text { (one mention each) }\end{array}$ \\
\hline
\end{tabular}


Table 5: Suggested solutions for traffic issues

\begin{tabular}{|c|c|}
\hline Problem & olutions and number of participants who suggested them \\
\hline Traffic in Solva & $\begin{array}{l}\text { - } \text { Heavy through-traffic should bypass Solva (2 locals, } 1 \text { tourist) } \\
\text { - } \text { Action the road-widening scheme that has already been planned (1 local) } \\
\text { - } \text { Pedestrian crossing ( } 2 \text { locals }) \\
\text { - } \text { Speed bumps ( } 1 \text { local, } 1 \text { tourist) } \\
\text { - } 20 \text { mph speed limit ( } 2 \text { locals }) \\
\text { - } \text { One way system in parts, like road works arrangement (1 local, } 1 \text { tourist) } \\
\text { - } \text { Restrictions to slow traffic down (1 tourist) } \\
\text { - Solva: Traffic lights ( } 1 \text { tourist) }\end{array}$ \\
\hline Traffic in St David's & 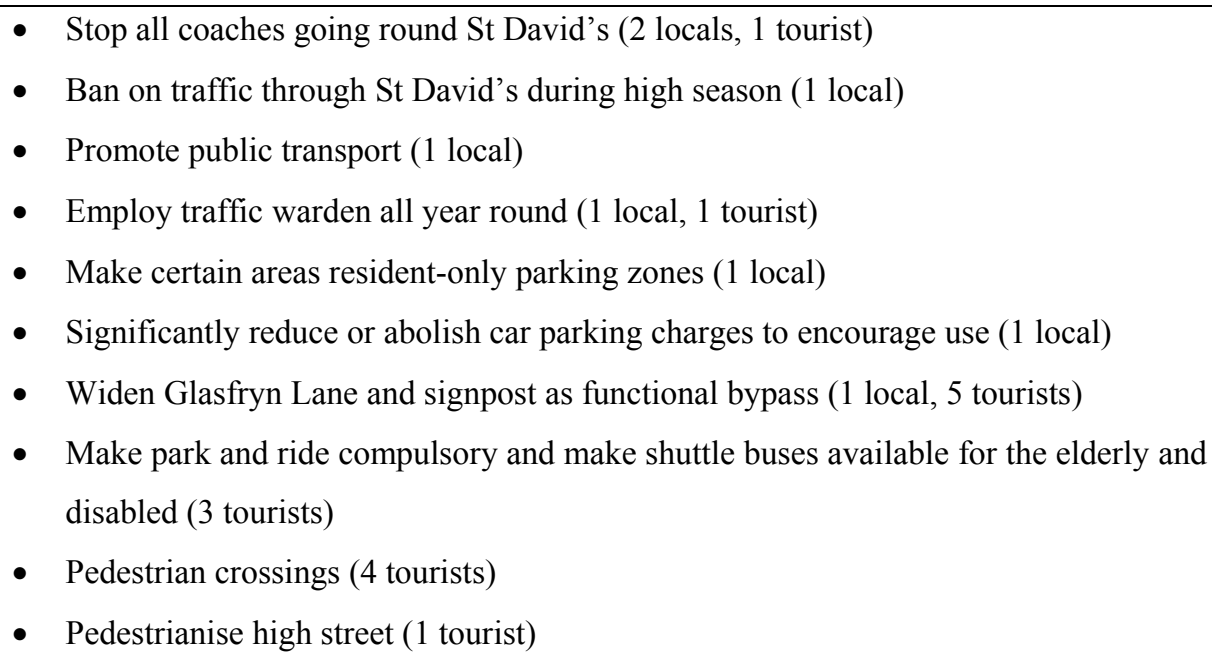 \\
\hline $\begin{array}{l}\text { Traffic on the } \\
\text { Peninsula }\end{array}$ & $\begin{array}{l}\text { - } \text { Park and ride service to the beach ( } 1 \text { tourist) } \\
\text { - } \text { Better ( } 3 \text { tourists) and cheaper ( } 1 \text { tourist) public transport } \\
\text { - } \text { Car parks outside the centres ( } 1 \text { tourist) } \\
\text { - } \quad \text { Hire traffic planners to solve the problems in the area! ( } 1 \text { tourist) }\end{array}$ \\
\hline Dangerous roads & $\begin{array}{l}\text { - The issue of four wheel drive vehicles is a national issue and should be dealt as such } \\
\text { ( } 1 \text { tourist) } \\
\text { - Ban } 4 \times 4 \text { s from narrow roads and small car parks ( } 2 \text { tourists) } \\
\text { (farmers) } \\
\text { - More footpaths ( } 1 \text { tourist) } \\
\text { - Delivery vehicles to be restricted to early morning deliveries ( } 1 \text { tourist) } \\
\text { - More cycle routes for bikes only ( } 1 \text { tourist) }\end{array}$ \\
\hline
\end{tabular}




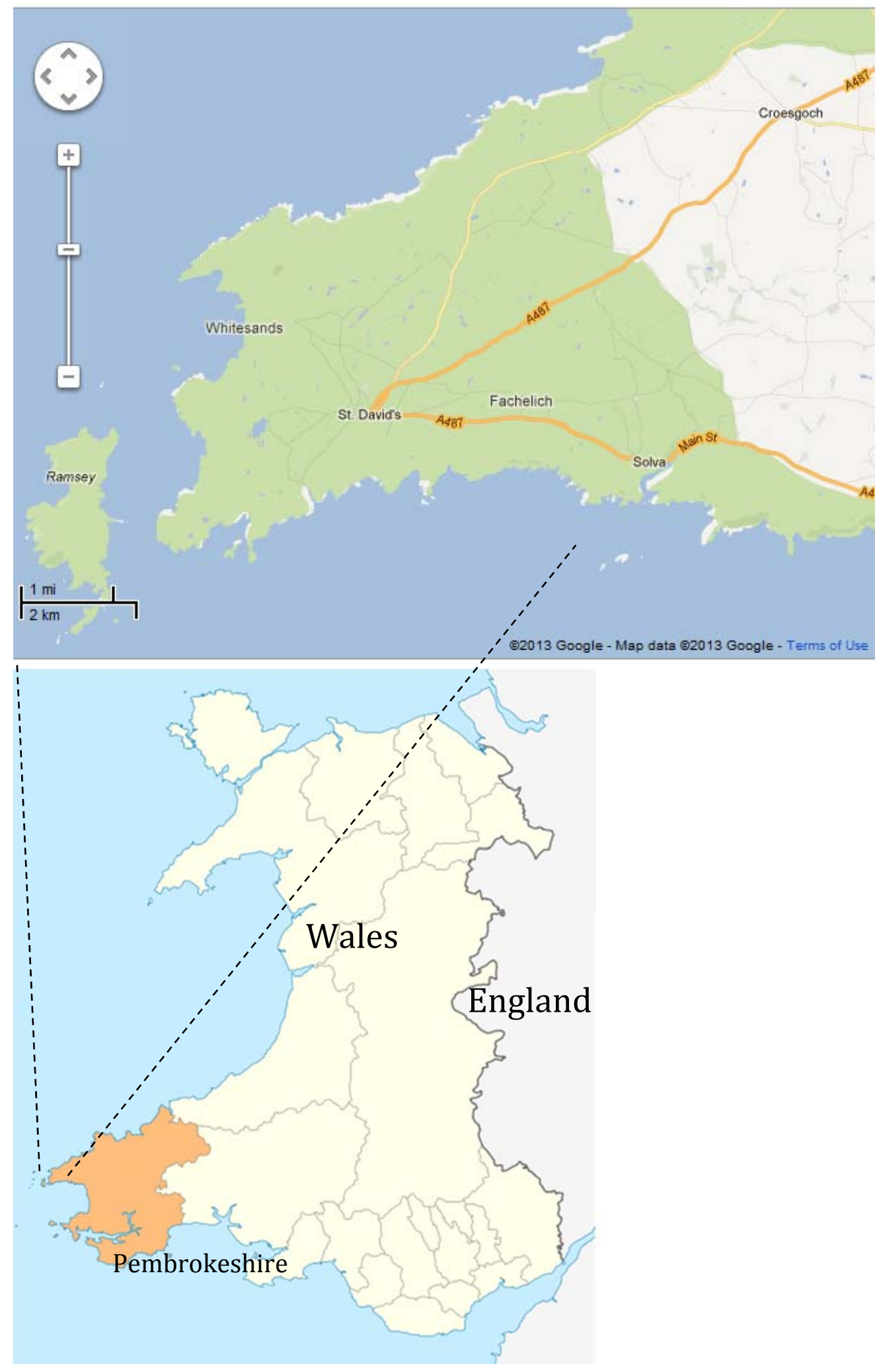

Figure 1: St David's Peninsula in Pembrokeshire Coast National Park (Google Maps, 2013; Wikipedia, 2013) 


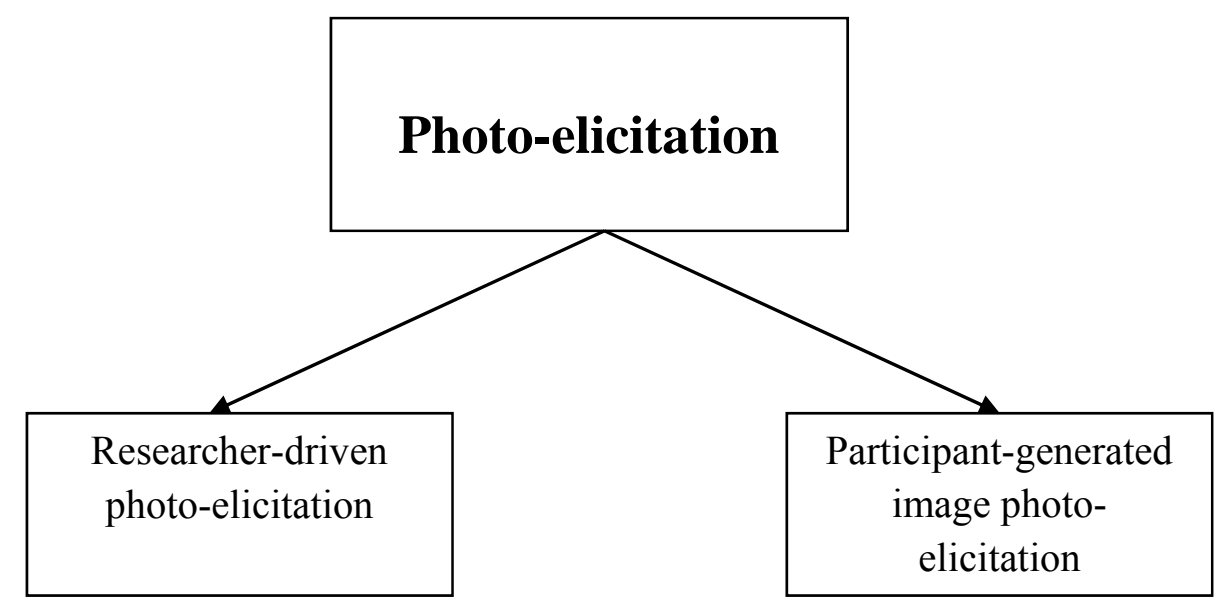

Figure 2: The two strands of photo-elicitation 


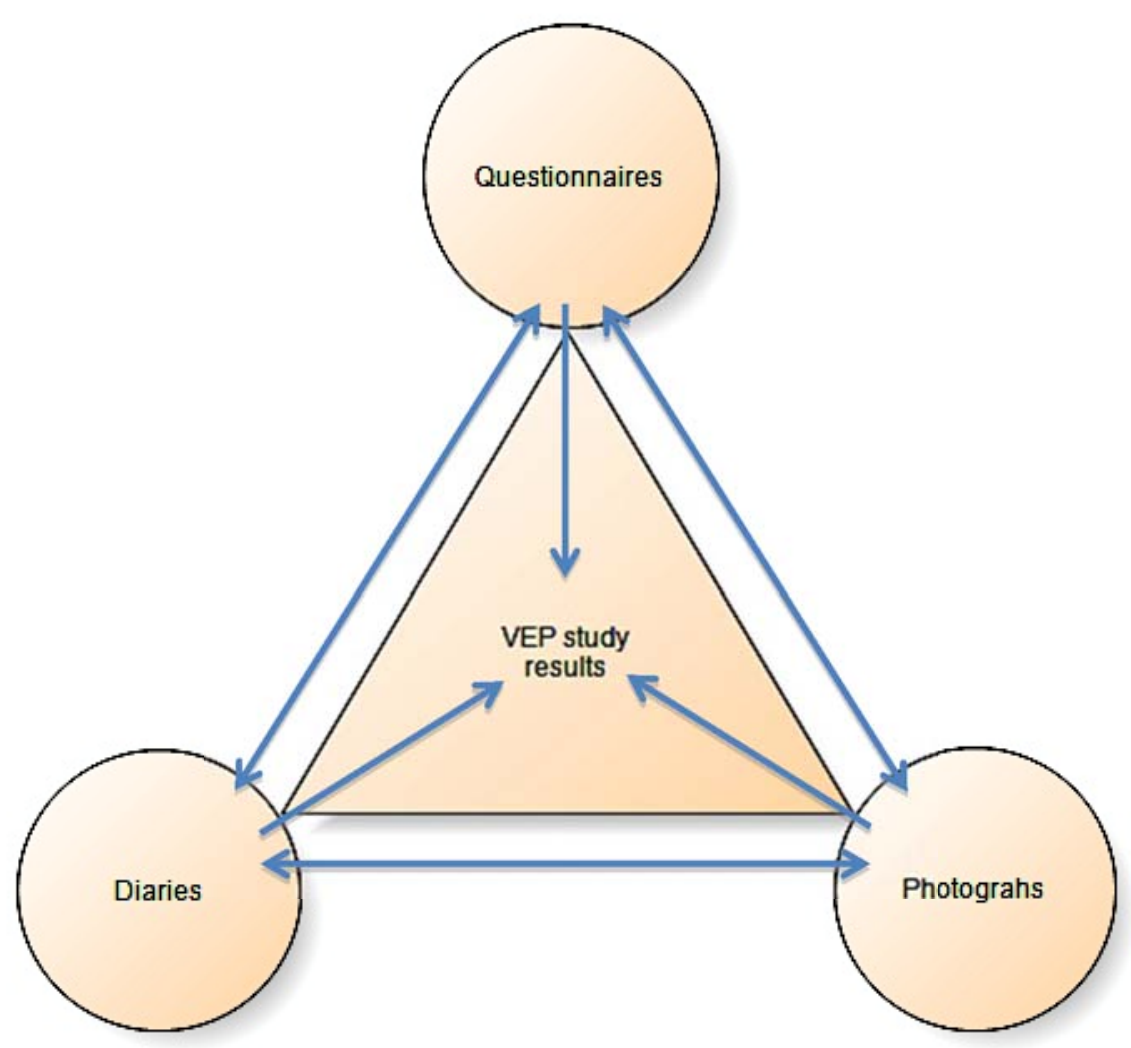

Figure 3: The VEP “triad”: interaction between its components 


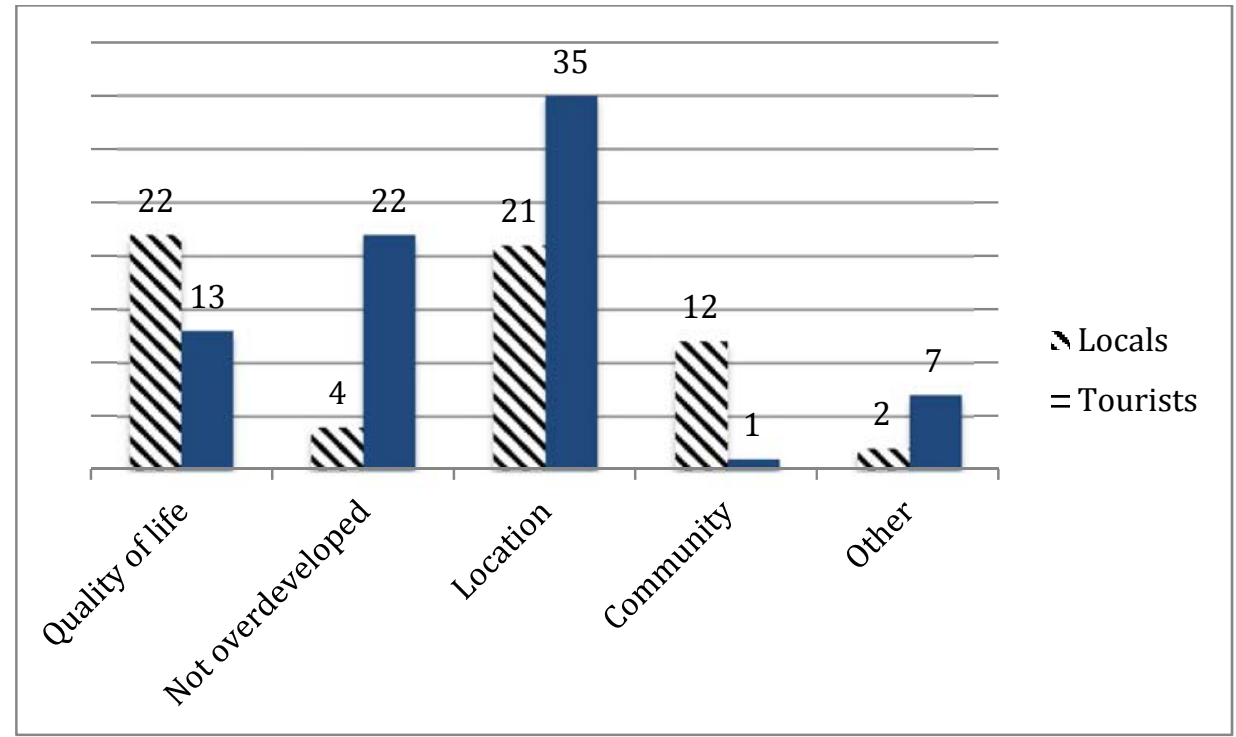

Figure 4: What is it that you value the most about this area? 


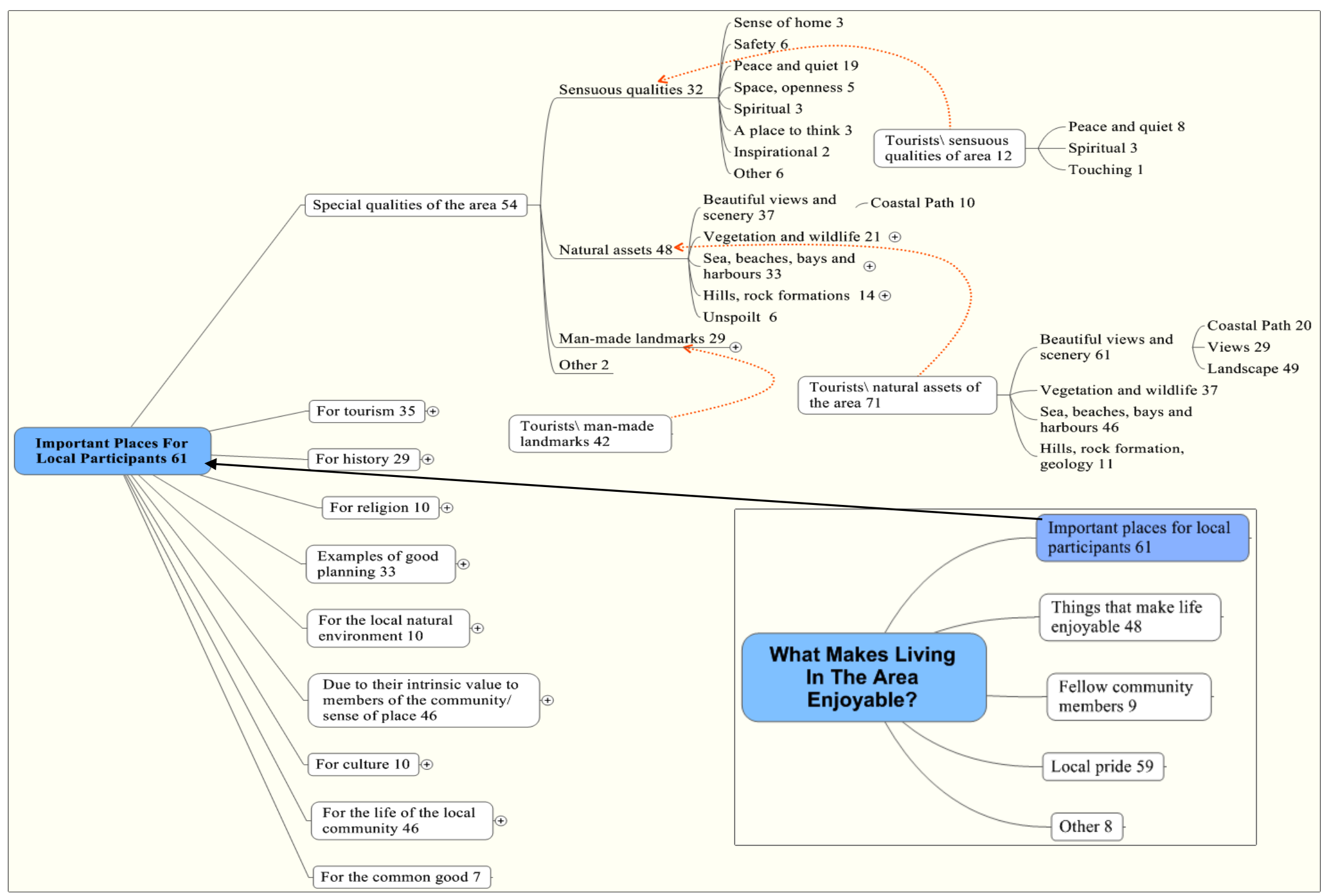

Figure 5: Important places for local participants and the focus of tourists' photographs and references

Legend: Tourists, in comparison to local participants, have only addressed the issues indicated by the red arrows. These indicate where each group of tourists' comments would sit in, in relation to locals' comments. 


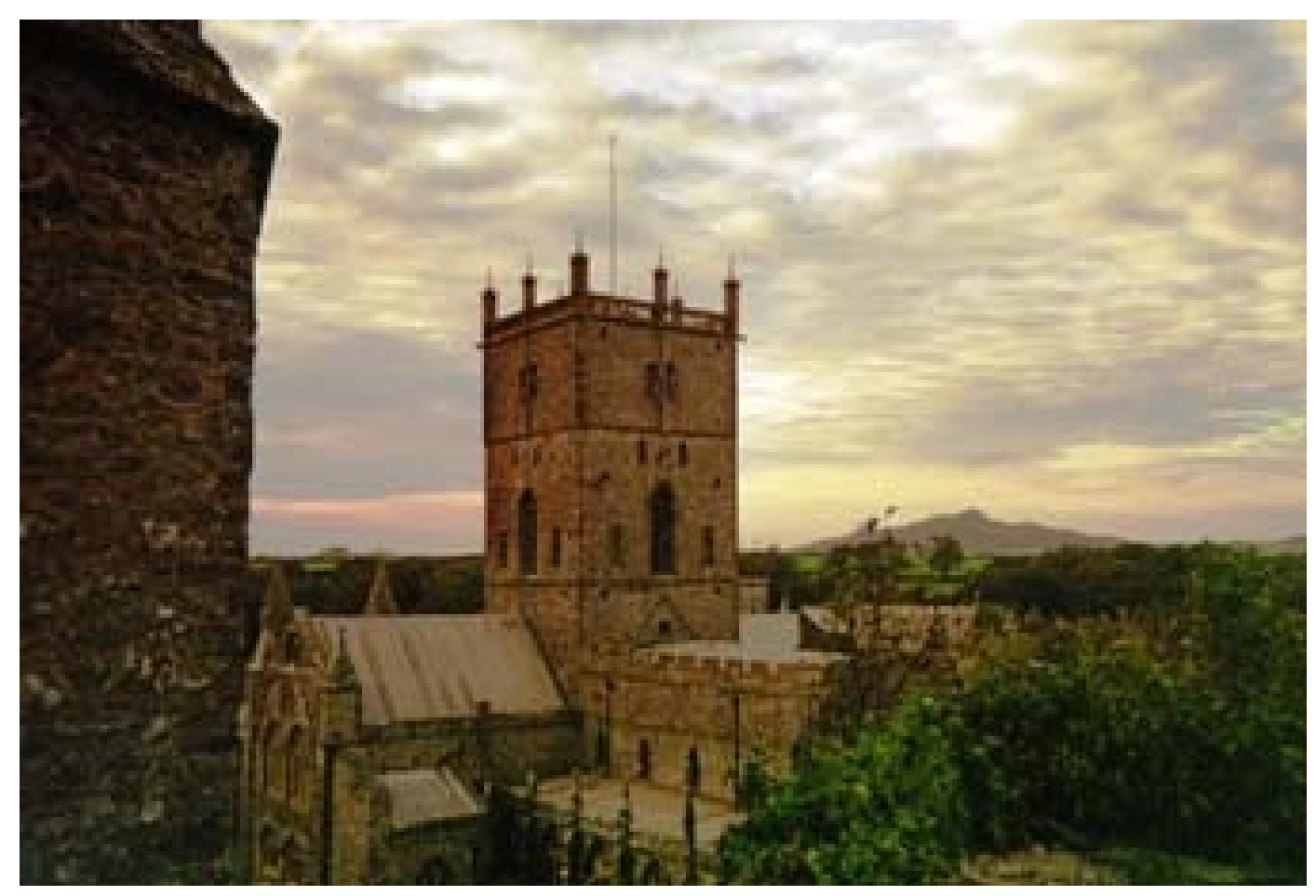

Figure 6: St David's Cathedral 


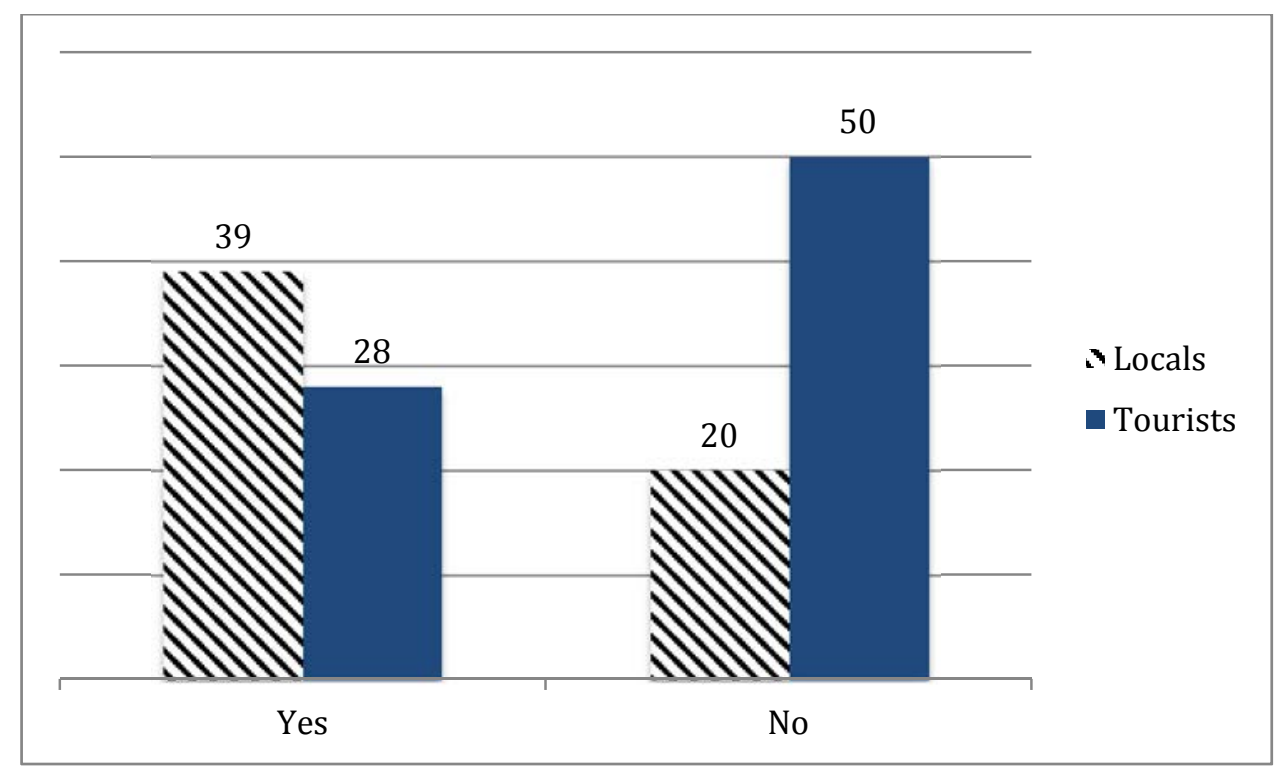

Figure 7: Are there any aspects of the area you do not like? 


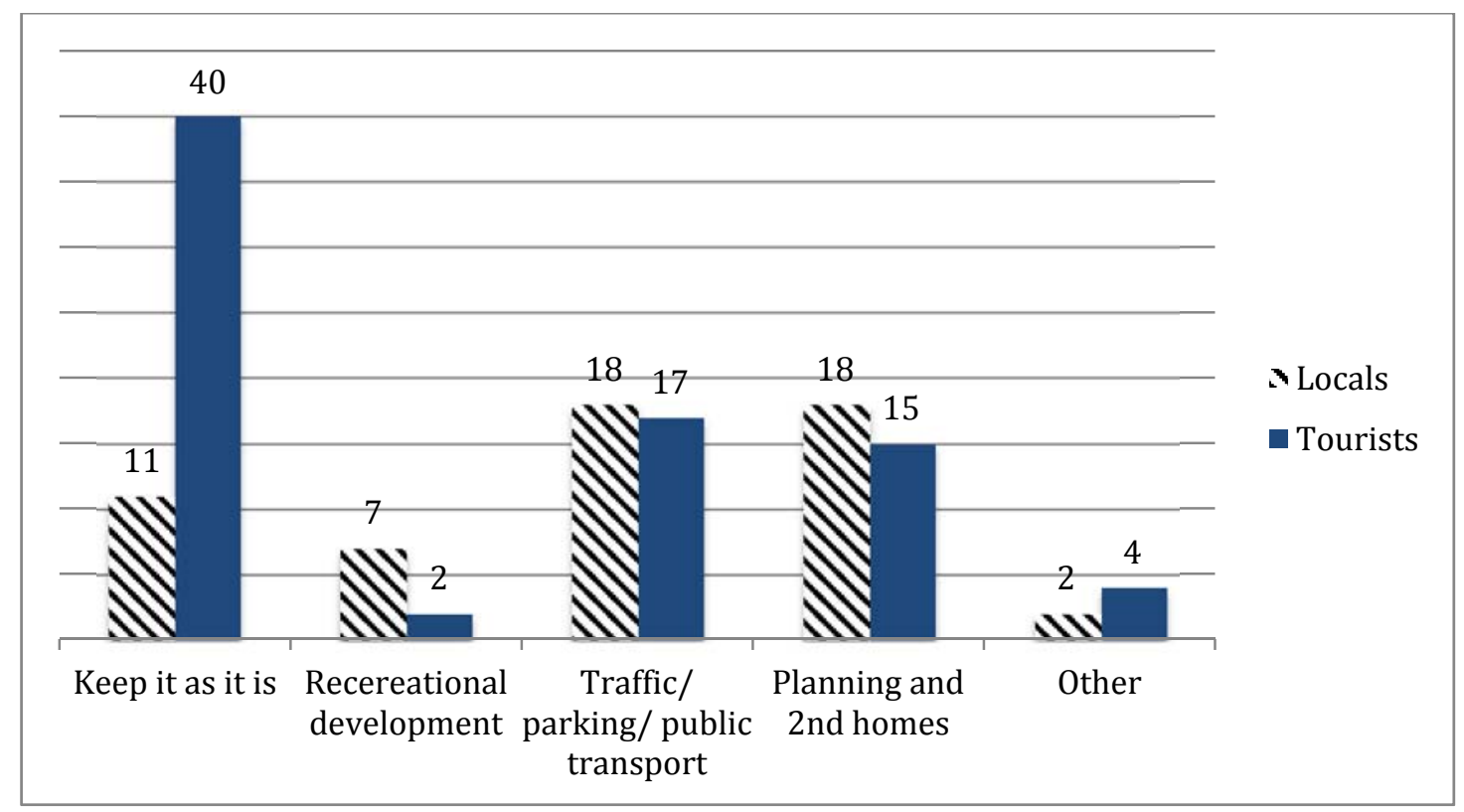

Figure 8: How can the area be improved? 


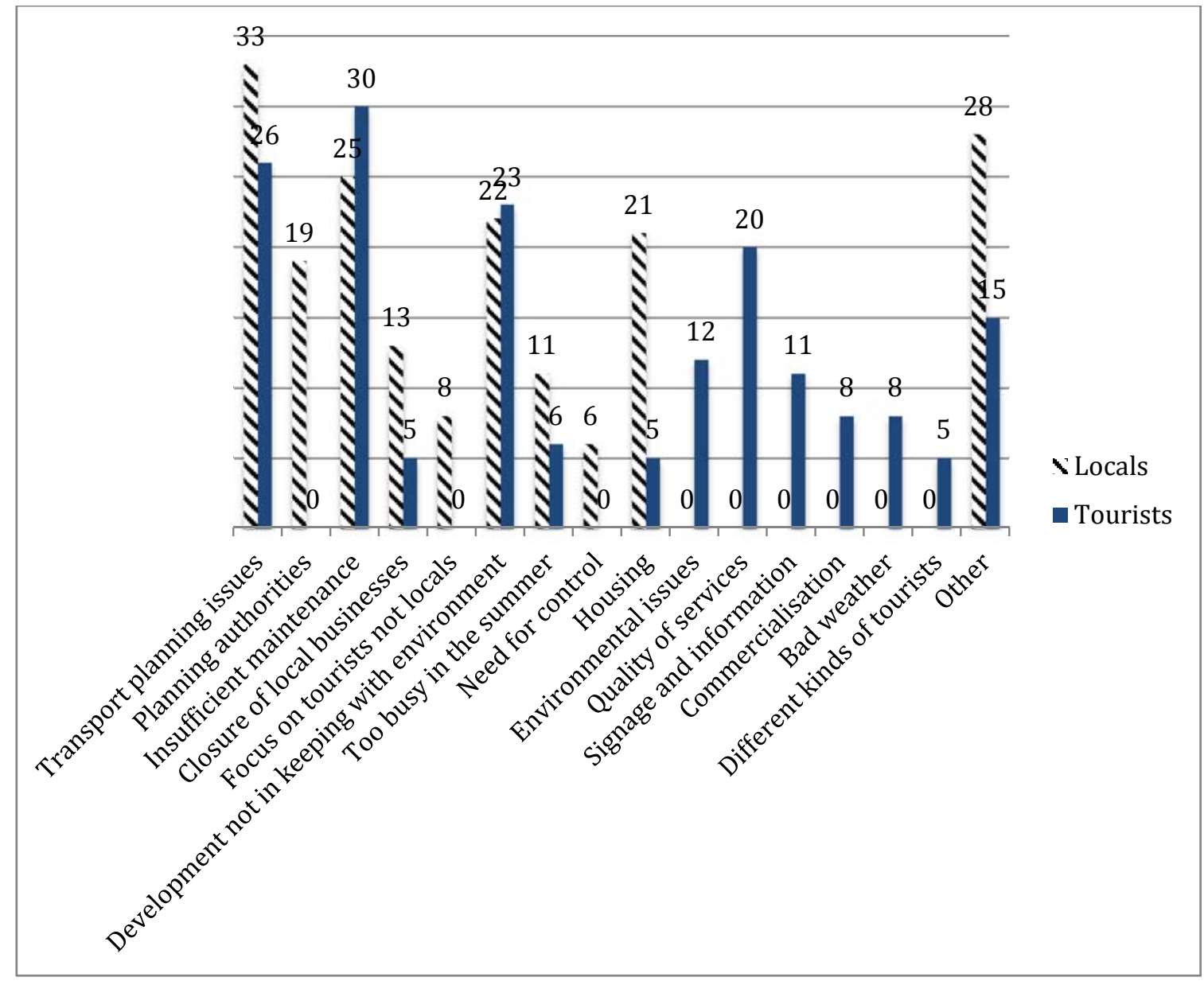

Figure 9: Identified problems 


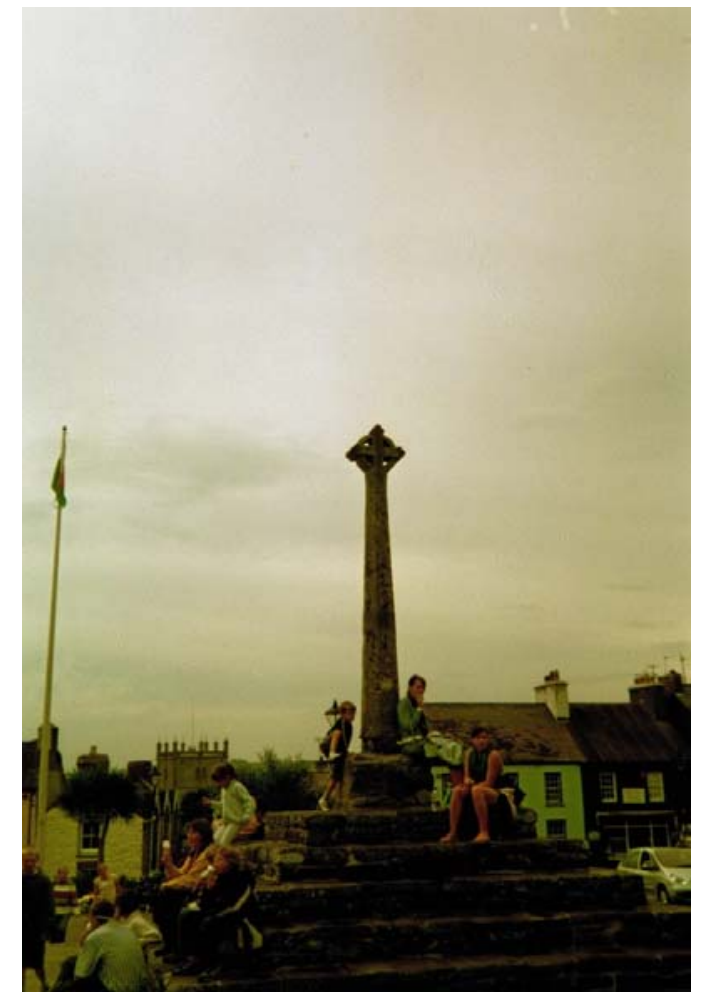

Figure 10: Cross square 


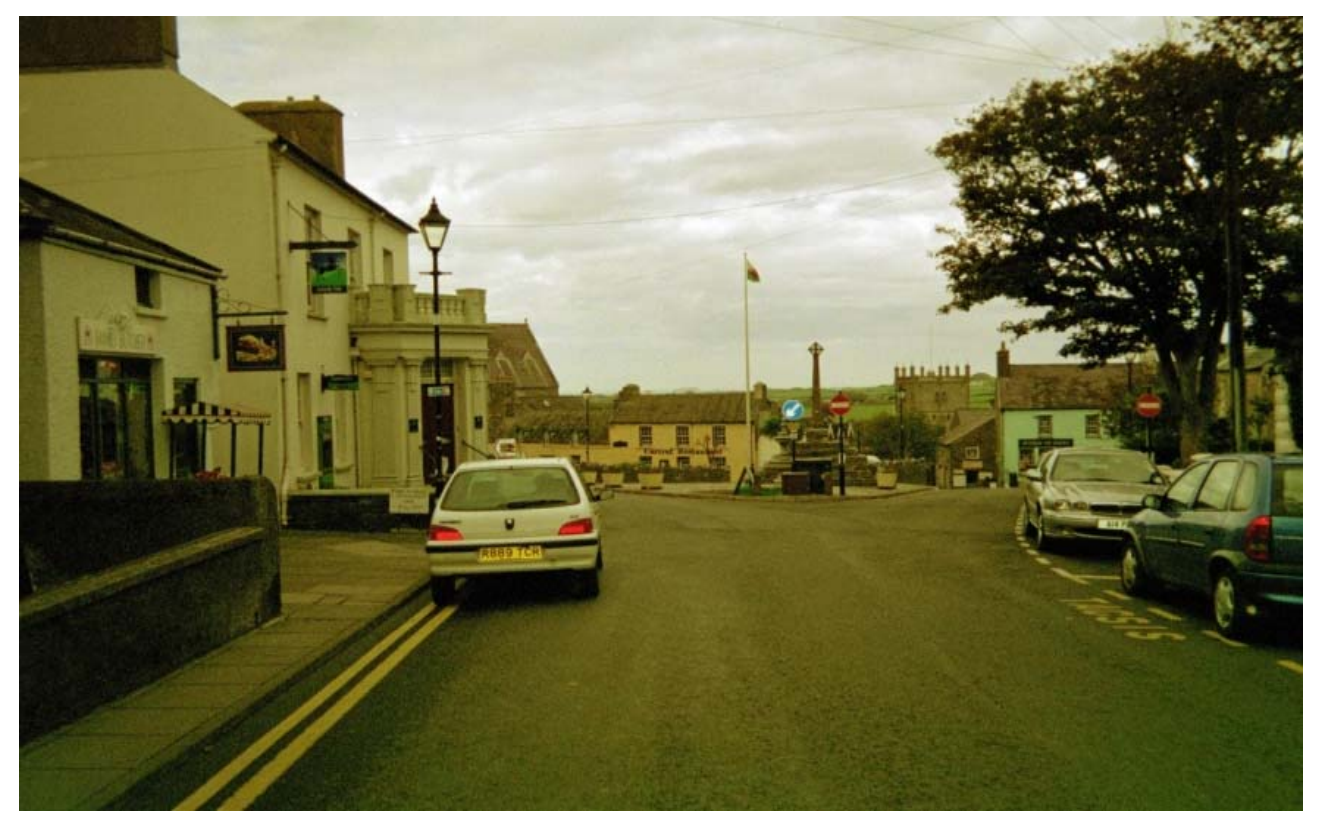

Figure 11: Cross square 


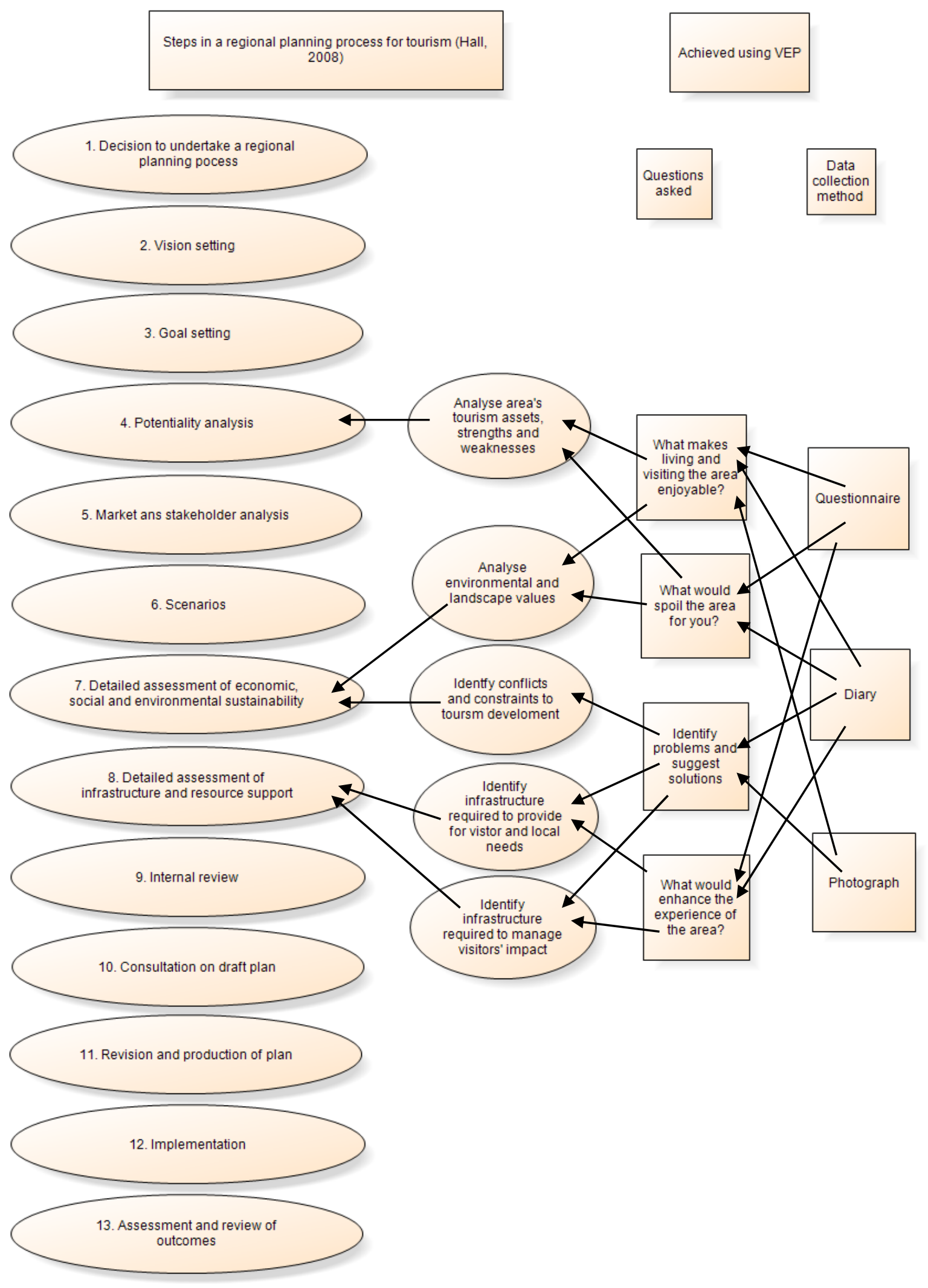

Figure 12: Using VEP to inform tourism planning in St David's Peninsula 